\title{
The Sudden Success of Prose: A Comparative View of Greek, Latin, Old French and Old Norse
}

\author{
Lars Boje Mortensen*
}

The article presents a new model for understanding the sudden success of prose in four literatures: Greek, Latin, French and Old Norse. Through comparison and quantitative observations, and by focusing on the success of prose rather than its invention, it is shown that in all four cases two or three decades were crucial for creating prose literature. This turn can be described by the term »librarization «: the fact that private book collections and reading habits emerged helps us understand the space into which a host of prose writers were suddenly writing. This reading habit factor (inlcuding reading aloud) has been underplayed in previous scholarship mostly focused on authorial choices and invention. For two of the literatures (Greek, French) the fast dynamics of the rise of prose has already been identified and discussed, but for the two others (Latin, Old Norse), the observation is new. It is also suggested that the exactly contemporary rise of French and Old Norse prose (c. 1200-1230) most probably is connected. The four literatures are each shown in chronological charts so as to visualize the timeline and the relation between poetic and prosaic works. The article furthermore reflects on a number of characteristics and implications of prose literature by drawing on comparisons and contrasts between the ancient and the medieval, important among which is the profound effect of prose librarization on the canonization of existing poetic literature.

Keywords: medieval literature; prose; poetry; book history; French; Latin; Old Norse; Greek; library history; history of reading

"So crowded were they [Plato, Aristotle, Isocrates etc.] into a brief epoch that there were no two worthy of mention who could not have seen each other. This phenomenon occurred among the Romans as well as among the Greeks. ... Though I frequently search for the reasons why men of similar talents occur exclusively in certain epochs and not only flock to one pursuit but also attain like success, I can never find any of whose truth I am certain, though I do find some which perhaps seem likely ... $\ll^{1}$

My point of departure for this comparative study is the common observation that in most European literary cultures (and others to be sure), poetic works precede the prosaic - often by a remarkably long period. The first systematic intercultural reflection on the chronological primacy of the poetic mode was made, probably, by Giambattista Vico in his Scienza Nuo$v a$ in the early eighteenth century. His twentieth-century admirer, Northrop Frye, adopts a

\footnotetext{
* Correspondence details: Lars Boje Mortensen, Department of History, Centre for Medieval Literature, Syddansk Universitet, Campusvej 55, 5230 Odense M, Denmark. Email: labo@sdu.dk.

1 Velleius Paterculus, Historia Romana, I. xvi-xvii , trans. Shipley, Loeb 1924.
} 
Vico-inspired civilizational scheme in The Great Code (1982), and in this connection he takes up another seminal book, Eric Havelock's Preface to Plato (1963). Instead of focusing on the technology of literacy and the educational aspects of the Platonic turn identified by Havelock, however, Frye prefers "... to associate the Platonic revolution with the development of continuous prose. Continuous prose, though often regarded ... as the language of ordinary speech, is a late and far from snaturak stylistic development, and is much less direct and primitive than verse, which invariably precedes it in the history of literature. $\aleph^{2}$

Not only is the appearance of prose late, it is also, in many cases, sudden. It is this dynamic aspect I would like to explore in book-historical terms, focusing on the success rather than the invention of prose. The importance of a critical mass of prose books can, furthermore, be brought out more forcefully with the help of multiple comparisons. ${ }^{3}$ I was first struck by some similarities between the dramatic expansion of writing in French and Old Norse in the decades around 1200. In French this development had already long been identified with, or at least seen as related to, the sudden rise of prose - but not so in Old Norse studies. My interest in the question was further aroused by the fact that in most literary histories of both French and Old Norse, the role of the surrounding sea of Latin prose is often downplayed and reduced to a discussion of "sources", as if with no dynamics in itself. The clerical setting of the beginnings of both written French and Old Norse, and the importance of translations and adaptations of Latin texts, seemed to call for approaches which took more seriously the interaction between the more recent written language ("vernacular" or "demotic") and the older high status language (»sacred «, "cosmopolitan«, or »imperial«). ${ }^{4}$ This led to a consideration of the emergence of Latin prose itself in the second century BCE because the role of Greek for the Romans was very similar to that of Latin in the western Middle Ages. Applying models from medieval vernacular languages it became apparent that Latin actually displayed a very similar and dramatic sudden success of prose - a success that had been overlooked by classical scholars who, like their medievalist colleagues, had been occupied with separate genre histories. The rise of a new prose literature, had, on the other hand been well described by scholars of classical Greek for the period around 400 BCE, when a surprising new start was as clear as in the French case. As I want to capitalize on the insights of scholars of Greek literature for the other three cases, I therefore hope that medievalist readers will bear with a chronological structure in which the cases of Greek and Latin are treated before medieval French and Old Norse.

An important premise for the present study has been to register all kinds of writing in the first phase of prose in each language and to break out of both national and genre-driven canons. While some of the results of the comparison may be less certain than others, I aim at least to have convinced my readers by the end that any explanation of the sudden emergence of prose cannot operate by focusing only at one (modern) place (Athens without Syracuse; France or Flanders without England, or Outremer; Iceland without Norway), nor by privileging certain genres. The establishment of a new prose literature in Antiquity and the Middle

2 Frye, Great Code, 8; cf. also 81.

3 In spite of its title, Godzich and Kittay, Emergence of Prose, deals only with French literature and it has a clear emphasis on the late medieval and early modern periods.

4 For the concept of Latin, Greek, and Arabic as imperial languages, see Høgel, World Literature is Trans-Imperial. 
Ages must instead be situated within each language, with all its literary and learned manifestations, and within a wider book culture. In order to make the case more succinctly and without a long narrative of literary history, I have devised four coloured charts which contain the most central information for each of the four literatures. We may not arrive at big data as in modern distant reading, but it does show that quantity and chronological patterns matter.

The value of comparison across Antiquity and the Middle Ages is not solely to list differences and similarities (although this is always a help against rash generalizations and exceptionalisms), but rather to generate critical questions that would never arise within a single field. Starting from the obvious case of French and supporting it with the case of Greek, I believe I can offer a new model for both Latin and Old Norse as well as point to a connection between French and Old Norse. But the implications of this reflect back on how we should understand the French case and in particular what it means to create a prose literature in a multilingual environment, as happened with Latin; I therefore hope that the classical parts will be valuable for medieval scholars and vice versa. At the end I suggest some general implications which, among other things, try to balance historical and book-historical framing with contingent factors, an area in which the ancient and medieval examples throw light on each other; I hope the wider implications may be useful for thinking about pre-print literatures in general, even when they do not display the pattern of a sudden success of prose that I argue for in these four cases.

It also needs to be specified at the beginning what is meant by a book and book-historical approach. The parameters of book history have mainly been defined by scholars within early modern and modern print culture, and it is now associated also with the material turn in literary studies: insistence on the importance of the physical framing of texts, their distribution and storing, reading habits, and the economy of books has made sure that we cannot deal only with abstract texts in literary history and theory. ${ }^{5}$ The concrete historical embodiment of texts is always important for interpretation. As regards medieval (and ancient) textual culture the physical and social aspects of books have in many ways always been at the core of the philological disciplines, which are intensely aware of the uniqueness of each handwritten copy and the fragile transmission of texts. But book history and the history of reading can be still be an inspiration for pre-print scholars to study the larger framework of textual culture, even if our data behave differently.

For the sake of convenience I call both the ancient scroll (volumen) and the medieval codex books. Although they differ in some respects, including the somewhat limited capacity of a scroll containing one "book" of an ancient work, the important distinction here is bestween a continuous prose text of many pages and other writing, such as inscriptions, letters and glosses, which are sometimes also characterized as prose. I am concerned here with book prose that is composed for sustained reading (private or public) and for long-term preservation and mobility, and in these regards the scroll and the codex are very similar.

5 Some influential scholars, within a field of a very wide variety of viewpoints and topics, are Roger Chartier, Adrian Johns, and Franco Moretti; the key international forum, with conferences and journal, is the Society for the History of Authorship, Reading and Publishing (SHARP). Gillespie, History of the Book, makes an excellent case for integrating pre- and postprint book history (within Anglo-American research, but the plea applies well to other geographies). 
The present comparison does not attempt to establish any single explanation for the lateness or the suddenness of prose literatures (in the four languages in question); rather I wish to add something to the explanandum: we should not only seek to understand why a few key authors "chose« to write prose instead of poetry (which ultimately might escape explanation), nor should we restrict ourselves to analysing the effects and potentials of prose writing within one literature (this has to a certain extent been done very well). ${ }^{6}$ What needs to be explained is a distinctive pattern emerging from the comparison and the results of quantitative reasoning within book history: a case can be made for all four literatures that there is a strong correlation between the sudden success of prose and the rise of private libraries and readership, and that this mutual reinforcement of prose production, dissemination and consumption reached a point of no return in a matter of a few decades, bringing along a fundamental change in the whole literary field. The expectation that books would circulate and be stored and read in private collections brought with it a wholly different horizon for writers who responded - and helped create book collections at a highly dynamic moment - by composing complex narratives, treatises, etc. that could be of use only as a part of a library and within a new, elite "public sphere« of readership.

To understand this process in terms of classic literacy/orality studies, one needs to add the term »librarization" as a third phase after "Verschriftung" (»literization«) and "Verschriftlichung" ("literalization«): the first phase is simple alphabetization as is often seen in early epigraphy and marginal additions to books in authoritative languages, usually very short texts. The second phase is the taking down (or composition) of longer poetic narratives like the Iliad or the Song of Roland, or of Greek and Roman drama in their early phases. ${ }^{7}$ The book medium made it possible to record and copy (and compose) such poetic works, but they were not part of a culture of book storage and exchange, because book collections dedicated to those languages did not yet exist. The book was a recording or composition and acted as an aide-memoire for the real work, the performance of the text. ${ }^{8}$ When librarization occurred, however, prose books were the works; the relationship between work, text and book became much more intimate: prose books were both thought of by their authors as having an immediate impact (often through recitation), and conceptualized as adding to physical libraries where they could be retrieved, re-read, re-circulated and used for reference. While the first steps of such book-collecting were no doubt haphazard and seemingly inconsequential, this new horizon of textual existence, preservation and possible long-term fame, eventually implied an idea of The Library: the accumulated, canonical works of the culture or language domain in question. This horizon of writing, I will argue, must also be understood in statistical and book-historical terms. The appearance of prose books opened up new mindsets and intellectual practices within the educated part of the elites.

This approach is not at odds with those literacy/orality scholars who emphasise the impact of the writing process even on what passes as the most orally composed or orally derived works: length, structure, linguistic features etc. could all be heavily influenced by the record-

7 The two latter translations from German are taken from Pollock, Language of Gods, 4; Pollock's thesis about Latin and the term »librarization" is discussed in another context by Mortensen, Latin as Vernacular.

8 The performance horizon of Roman drama and poetry is powerfully argued for by Wiseman, Roman Audience. 
ing and co-composition of scribes. ${ }^{9}$ For early Greek and Roman playwrights, for example, writing was probably an important part of literary creation (whereas actors, at least in some contexts, were taught their lines orally). But in both cases these processes did not create a reading public, let alone book collections and expectations of future library- and school-supported canons.

\section{Greek}

In ancient Greece prose was contrasted to both song/poetry (aoide/poiesis) and myth (mythos) by the ubiquitous term logos (speech); or rather the more restricted sense of logos when it was clear that writing was involved (»written discourse«), later sometimes specified as "discourse on foot " (pezos logos). ${ }^{10}$ The other important, and more precise word for prose was syngraphé (»writing put together"), syngraphein (»to write together»/to write prose). These more or less technical terms show up in the decades just around $400 \mathrm{BCE}$, the precise syngraphé in the long and complex writings of Thucydides, Xenophon and Plato. Whether logos could already much earlier - as in the pre-Socratic philosophers - be a technical term for prose is impossible to tell as it can always be understood as »speech", »discourse«, »reason", and "argument" as well. Syngraphé obviously refers to the written composition of longer works and is not used about earlier letters or law inscriptions (from the sixth or fifth century); they are just writing, not »writing put together«.

In modern scholarship the issue of a new dynamic of writing around 400 BCE was powerfully raised by Eric Havelock in his Preface to Plato (1963), later revised and summarized in other works such as The Muse Learns to Write (1986). Havelock was a pioneer in arguing that we do not have a series of works of literature from Homer to the Hellenistic age, as their modes of existence, storage and diffusion differ so widely. Until the age of Plato (427-347 BCE) the dominant way of storing wisdom was in verse, and not necessarily verse composed with any idea of writing. The norms and cultural identity of Greek societies were encoded in various poetic forms, including epic, didactic poetry, drama, and lyric.

According to Havelock, Plato's passionate and consistent hostility towards the poets, which had never been properly explained before, had nothing to do with literary or aesthetic taste, but everything to do with his ardent wish to institute new norms and a new education based on his kind of philosophy. The insights of conceptual abstract thinking, made possible by the shift from the ear to the eye, from the oral to the written, had to oust the metaphorical and poetic as a basis for Greek education. This breakthrough by Havelock happened simultaneously with other important developments in the wider debate about orality and literacy (associated with Jack Goody, Marshall McLuhan and others) and became very influential outside of classical studies. ${ }^{11}$ Havelock's work now ranks as a classic in the "Great Divide" debate where he is grouped with those in favour of technological explanations for change as opposed to scholars who put greater emphasis on the ideologies being furthered by writing. In studies of Homer, Plato and Greek literature, Havelock was severely criticized and subsequently largely ignored. This reaction seems to have been due to the provocative novelty of 
his views and perhaps also for what could be termed his idyllic depiction of the pre-literate Greek mentality; the primary reason, however, was that it undermined entrenched positions in teaching and scholarship about the antiquity of the Greek alphabet (where Havelock's late date around 700 BCE is now mainstream), about Homer as an author, Plato as a thinker and about the long continuities in Greek civilisation. ${ }^{12}$

When the emergence of Greek prose was put directly on the agenda in 2002 by Simon Goldhill in The Invention of Prose, he also ignored Havelock, while in essence taking up his views about the crucial dynamics around 400 BCE. Goldhill brilliantly analyses the effects of Greek prose over the entire range of genres, from history through rhetoric to philosophy and science and further ahead to the novel, the satire, the Gospels etc. This includes a focus on reasons/causes (aitia) in history, science and philosophy, and on the self-reflective aspects of a new kind of authorship and readership: Thucydides, for instance, famously launches the idea, later to become a historiographical topos, that the explanations and narratives are greater than the deeds themselves, clearly an observation that contrasts with the epic voice. Critically, Goldhill lays to rest the perception that was dominant in classical scholarship, and beyond, that prose could be seen as a natural and transparent development in literature. ${ }^{13}$ Even more than Havelock, he shows how fully the Greeks capitalized on the potential of the new medium of prose in narrative literature and in organisation of theoretical knowledge from the late fifth century until the Hellenistic Age.

Some voices have been raised in favour of a much earlier revolutionary moment as the birth of Greek prose, namely the Milesian philosophers of the sixth century. ${ }^{14}$ The views of Thales, Anaximander and Anaximenes (impossible to date precisely) are known from Aristotle and later references, but they all survive in reports without any certain direct quotations of any length. As Havelock points out, it is even highly dubious whether the Milesians actually wrote anything. ${ }^{15}$ Both Havelock and Goldhill are criticised by Markus Asper for ignoring this early discursive prose and he raises a number of interesting possibilities about how the invention of prose came about, for example, expanding on lists, its correlation with the writing of laws and more. It is not possible for a non-specialist to weigh the complex and late testimonies, but if the Milesian philosophers really did write prose treatises perhaps as early as c. 570-50, we cannot form any idea of what their prose was like, nor of a book medium (papyrus?) or the preservation and circulation of the texts. On the latter point, however, Asper clearly states that we should not imagine any book trade and that the decisive point for prose was "probably Athens of the late fifth century. ${ }^{16}$

See, among others, Solmsen's review in American Journal of Philology and Gulley's in Classical Review, 14, 1 (1964) 31-33.

13 Best seen in the underlying assumption of Norden's classic work Antike Kunstprosa, as if this were an extension of a «natural prose

14 By Wöhrle, Zur Prosa der milesischen Philosophen, and especially by Asper, Medienwechsel und kultureller Kontext.

15 Havelock, Linguistic Task.

16 Asper, Medienwechsel, 98: „Über einen organisierten Buchhandel dieser Zeit, überhaupt über die Zirkulation nich-geschäftlicher Texte sollte man sich keine Illusionen machen«; and 101: "Die entscheidende Phase des hier behandelten Medienwechsels ist aber wohl erst das Athen des ausgehenden 5. Jhr. gewesen.» 
Criticism of the Havelock and Goldhill view of the triumph of prose rationality and discursivity in the late fifth century has also been levelled from another side, namely via the low, comical voice of Aesop. In Leslie Kurke's recent book Aesopic Conversations: Popular Tradition, Cultural Dialogue, and the Invention of Greek Prose the legendary fable teller is used as a lens for discovering the burlesque element of early prose works, especially in Herodotus and Plato. Both authors mention Aesop, and in Herodotus he is called a logopoios (story-maker), a description also used there for another early prosaist, the historian and geographer Hecataeus of about two generations before Herodotus himself. ${ }^{17}$ Famously, Socrates is described in Plato's Phaedo (6od-61b) as having spent time in prison putting Aesop's fables into verse. To us Aesop is a mythical figure, but the much later Life of Aesop (from the Roman imperial age) seems to place him in the early sixth century with a traditional death date of 564. The same Life mentions that Aesop wrote down his stories and fables and deposited them in a library, perhaps, it has been imagined as that of King Croesus of Lydia. ${ }^{18}$ In the Hellenistic and Roman period it seems that Aesop became the legendary inventor of this prose genre. ${ }^{19} \mathrm{How}-$ ever, even if Kurke's readings are very illuminating, they do not have any consequences for a book-historical approach like the present one, because there is no evidence that Herodotus, Plato, or Socrates knew of any book containing Aesopic material. He was seen as the inventor of a certain kind of story (not in verse) and Kurke describes this, consistently with the evidence as an "oral prose genre«. But as pointed out by Frye (above), it is unfortunate that there is no distinction made between prose in the stricter sense (written in books) and oral storytelling. With this distinction in mind, one might list Kurke's contribution on the same side as Havelock and Goldhill, as she tries to highlight a common trend in the first generation of prose writers known to us, that beginning with Herodotus, Xenophon, and Plato. ${ }^{20}$

Before presenting my own understanding of the dynamics of Greek prose writing, I would like to illustrate by means of a quotation what I mean by the "degree of book culture in the term librarization and the habits it involves. ${ }^{21}$ Plato's dialogue Phaedrus opens with a setting that clearly shows how integrated papyrus books were seen to be in intellectual life. Phaedrus is usually placed among the middle or late Platonic dialogues, perhaps composed then around $360 \mathrm{BCE}$; there is no indication of when the conversation was supposed to have taken place, so the indeterminate time of the action is assumed to be somewhere in the decades before Socrates' death (399 BCE). In the dialogue, Phaedrus has visited the famous orator Lysias, and he wants to convey to Socrates the speech Lysias gave about love; Socrates is eager to hear it and urges Phaedrus to reproduce the speech:

"Socrates, my good fellow, what do you mean? Do you think that I, an amateur, will be able to repeat from memory in a way worthy of Lysias, what he, the cleverest of present writers, has put together at leisure over a long period of time? « Socrates teases him that he had surely rehearsed the speech by reading it as well but Phaedrus protests that he can only give the contents of the speech in his own words: "I did not learn it word for word « [...]

Ch. 100 of the G-version, cf. Hägg, Art of Ancient Biography, 116.

19 Hägg, Art of Ancient Biography, 117.

20 And she also acknowledges (p. 15), in the same way as Frye and others, the unnaturalness of prose, and here she must be thinking of prose written in books.

21 Cf. Mortensen, Latin as Vernacular. 
Socrates: "Yes, my dear fellow, after you've first shown me just what it is you have in your left hand under your cloak; for I suspect you have the speech itself. ${ }^{22}$ After Phaedrus admits to his ruse, they go to a shady place and Phaedrus reads the speech aloud for Socrates. This snapshot of private book ownership and use shows us what had become the norm during Plato's lifetime; and it should not, I believe, be projected further back than the last quarter of the fifth century.

We are in fact looking at a very short timespan in which Greek literature took the qualitative leap from writing as merely recording or composing a performance for some practical convenience or ritual context (lyric, epic, dramatic), a state which lasted centuries, to the situation depicted in Phaedrus where books, readers and book collections were the horizon against which authors conceptualized written works in the new medium of continuous (book) prose. This is basically in line with both Havelock and Goldhill, although they are mainly concerned with the complex possibilities and effects of prose rather than the conditions for its rise and sudden success.

My argument is best presented by the help of Fig. 1 .

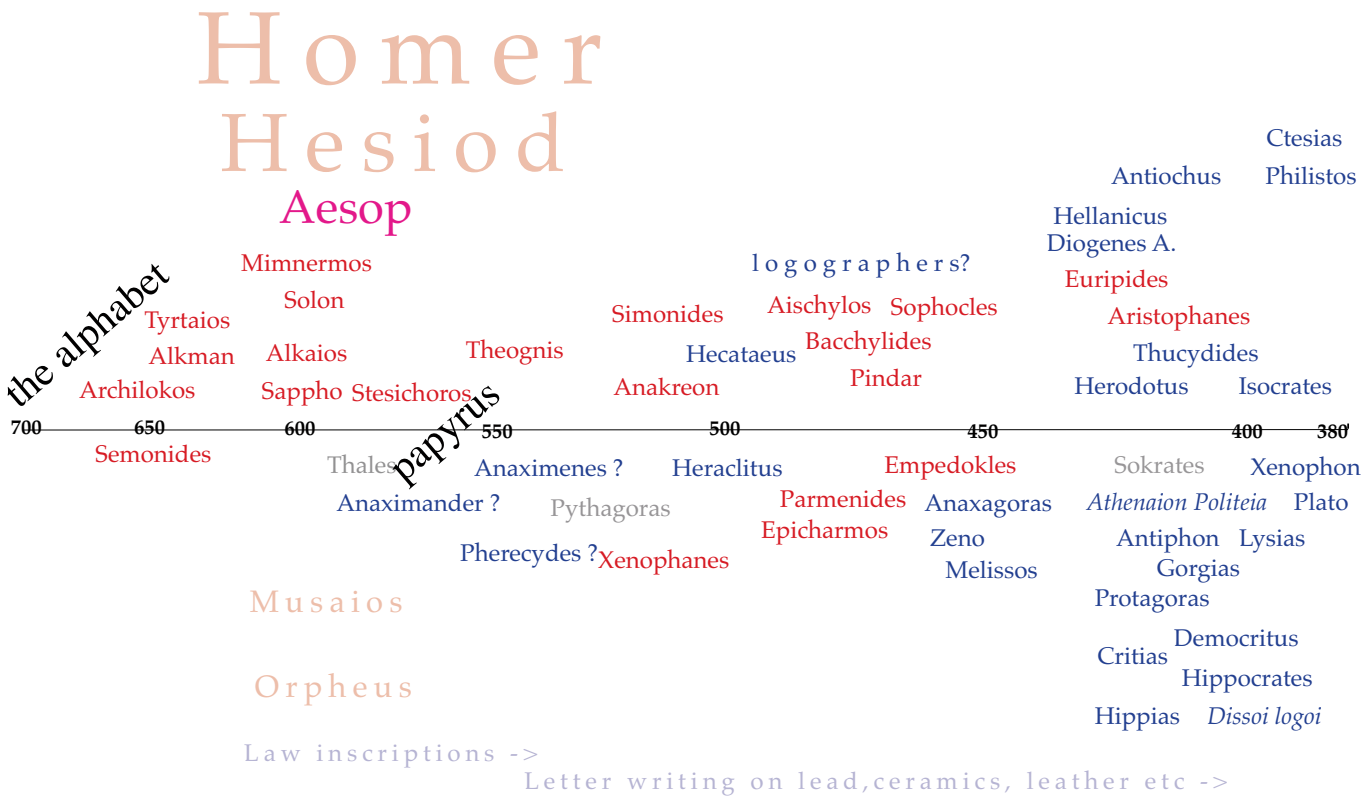

Figure 1: Greek 700-380 BCE

Main authors and texts are placed along a line starting with the spread of the alphabet around or just before $700 \mathrm{BCE}$ and through to the period around $380 \mathrm{BCE}$ which can be taken as a definite point of no return for librarization. The easy-to-handle-and-store papyrus book form was a crucial, though not sufficient, condition for the new book culture, but it is not known when papyrus was introduced as a writing material from Egypt to Ionia and mainland Greece. No early scraps survive, but it is usually presumed that long Greek texts like the Homeric poems presuppose papyrus as writing (and storing) material, and that, 
therefore, at least by the sixth century papyrus was used for books (although skin is certainly a possibility, and sometimes referred to as ancient writing material). ${ }^{23}$ Shorter texts were no doubt inscribed in the early period on other surfaces, like stone, leather, wood, ceramics, wax and lead; one report tells us that the Hesiodic poems were kept in Boeotia on very old worn lead tablets. ${ }^{24}$

On the chart the dates for texts and authors follow standard handbooks, and the names are placed so that, as far as possible, they centre on the main timeframe of writing (for authors pre-dating the fifth century the dates are often very uncertain). ${ }^{25}$ Poetic authors are indicated in red, prosaic in blue, and philosophers who were famous but left nothing in writing in grey. For the early period possible prose authors are listed among the completely dominant poetic ones, but in the late period (c. 430-380 BCE) it has not been possible to include all known poetic authors. This exclusion has no direct relevance for the argument which is about the explosive rise of complex prose in the decades around 400 BCE.

I am following the authority of Gregory Nagy in taking both Homer and Hesiod as personifications of oral poetic traditions covering a vast space, and furthermore in not opting for one of the many datings of their fixation in writing, spanning from the ninth to the late sixth century. ${ }^{26}$ Again, this has no bearing on the present discussion, but it would be grossly misleading, also for understanding the prose turn, not to have them represented somehow in the figure. For the sake of completeness two other anthropomorphised poetic traditions of importance for the Greeks, Musaios and Orpheus, are also listed (although in contrast to Homer and Hesiod rejected as real poets by all modern scholarship!); so is Aesop as a similar personified inventor, in his case of non-versified fables or stories, rather than a real writer of prose (as discussed above).

Finally the inceptions of law inscriptions and letter writing have been indicated. The writing of laws and letters is potentially important for the habit of writing prose books. In the Greek case, however, it must be kept in mind that law inscriptions before the Gortyn inscription of c. $450 \mathrm{BCE}$ are very short and do not have much in common with continuous prose. ${ }^{27}$ Similarly the early extant Greek letters, beginning with lead letters of the second half of the sixth century, were basically conceived as short oral messages in writing; only in the late fifth century, coterminous with the prose turn, do letters become literary and much more common; finally, specific letter-writing formulas are developed during the fourth century, as pointed out by Paola Ceccarelli. ${ }^{28}$ Another of her findings is also important for understanding the role of writing before c. 420 BCE: letters as represented in dramatic plots and even in Herodotus are seen as something sinister, deceitful or threatening. This complies well with the little we know of scribes who took down poetry in the sixth century; they have a reputation for tampering with the real, of course oral, wording of a poem or oracle. ${ }^{29}$

Ceccarelli, Ancient Greek Letter Writing, 28.

Pausanias, Description of Greece, 9.31.4, ed. Jones et al.

5 In particular Zimmermann, Literatur der archaischen und klassischen Zeit.

26 Nagy, Hesiod and the Ancient Biographical Traditions.

27 Cf. Gagarin, Early Greek Law.

28 Ceccarelli, Ancient Greek Letter Writing, 28.

29 Skafte Jensen, Writing of Homer, 305. 
Concentrating on the prose authors from left to right, there seem to have been three small clusters before the decades around 400 BCE, namely (1) the early Milesian philosophers; (2) Heraclitus, Hecataeus (and perhaps some other »logographers" already around 500 BCE) in Asia Minor; (3) Anaxagaros and perhaps two other philosophers from around 450 BCE (Zeno and Melissos). All three categories are poorly attested, like those covered by the blanket description given to earlier prose writers by Herodotus and Thucydides, "logographers", who also include Hecataeus and Hellanicus. The first group have already been dealt with above: even on the most optimistic interpretation three or four Milesian philosophers wrote their opinions down in one book each. We have no way of knowing if their writing qualified as continuous prose, but given the lack of audience for such works, they can hardly have been anything else than recordings of opinions for safekeeping. Such was the case with Heraclitus' book which is better attested, and known to have been a collection of aphorisms deposited in a temple. The proverbial character of Heraclitus' text and its temple dedication rank it with other, poetic, wisdom literature of the Pre-Socratics, not as a forerunner of a prose literature destined for circulation and reading.

Hecataeus' works on geography and myths may have been the first books to feature continuous prose, although some of it seems to have had a list-like character too. As stated, the small group of "logographers " (and logopoioi, storymakers), with Hecataeus usually counted as the earliest example, can hardly be construed as a trend following his example; for this they are too poorly evidenced and dated, or simply too late. ${ }^{30}$ The third group brings us to Athens with Anaxagoras and a more certain reference to his single work around 450 (Zeno and Melissos were not Athenians and their dating is less secure).

What these possibly early experiments of writing prose boil down to then - and on a critical reading only Hecataeus can be claimed to have used prose as more than a single recording of oral wisdom teachings (cf. Havelock) - is an emphatically secondary activity which evinces no inner development or traction of its own. It is to be likened to the poetic written texts which are agreed to have been taken down before the prose turn approximately in the century before (c. 525-425 BCE), beginning with the first attested Peisistratean writing of the Homeric poems and including first and foremost drama in Athens and Syracuse. The writing of drama was probably necessary as a creative tool for authors and as an aide-memoire for instructing actors, but it was based on a use-and-discard textual culture, which is why we possess almost nothing of the early drama today. Aischylos, Epicharmos, Sophocles and others constantly wrote new plays for competitions and little care was taken to preserve old ones, a situation which changed with Euripides. The performances were central to city life and culture, whereas the texts were not destined for a library or a canon, because book collections as canons of literature and repositories of written knowledge did not yet exist. There is an ancient tradition that the tyrant Peisistatros of Athens (d. 527 BCE) established the first library, but this is without a doubt a later projection giving a famous ruler more than he deserves (like the supposed library of Croesus mentioned above); the recording (or recitation) of the Homeric poems at his or his son Hipparchos' (d. 514 BCE) court led to this later inflated report. ${ }^{31}$

30 Cf. Goldhill, Invention of Prose, 10 on the prose predecessors of Herodotus and on his claim to be the first substantial and influential prose writer.

31 Too, Idea of the Library, 19-24. 
When Herodotus completed his voluminous Histories around $430 \mathrm{BCE}$ (or slightly later) he is very clearly perceived as having made a $»$ radical departure ${ }^{32}{ }^{32}$ His book is indeed the first continuous prose book in the entire world we can still read from cover to cover, and it is not improbable that it might still claim this priority even if the texts of Hecataeus or another logographer or early philosopher had survived. What is often forgotten, however, is that Herodotus had contemporaries who also wrote continuous prose, some of them several or many works (also including poetic ones); these include sophists and philosophers like Protagoras, Hippias, Critias, Diogenes of Apollonia, the historians Hellanicus and Antiochus of Syracuse, and the orator and speech-writer Antiphon. The dates of the lost writings of all these politicians and intellectuals (and often both) are not known with precision, but their existence is attested with certainty. Judging from what we know of their lives and later references to their works, a good number of these writings fall within the 430 s and/or 420 s BCE, contemporary with Herodotus' work and also with the moment Thucydides claimed he had begun writing his magnum opus on the Peloponnesian War (it began in $431 \mathrm{BCE}$, and he continued writing towards its end in 401). So while Herodotus was no doubt breaking new ground, he may well have seen others around him who also composed books in prose. It is a common, and very relevant and valid observation, that while the prose of Herodotus, who is reported to have travelled about and given readings from his book, still has a flavour of oral tales that have been written down (although with a superb overall composition), the complex prose of Thucydides is on all levels a very written product, destined for reading and for the Library as he famously says in the opening: "a possession forever " (I, 22).

The book medium and the idea of keeping and reading books must have spread in this way, although still very thinly and experimentally, over most of the Greek world during the 430 s and 420 S BCE; this was significantly consolidated in the 410 s and 400 S BCE: many works, probably including the encyclopedic philosophical effort by Democritus, belong here, as do the written speeches of Gorgias, but again we have few precise datings. It is in the decades from 400-380 BCE, however, that we are on firmer ground, statistically and in terms of content and attitudes.

In these two decades the innovative authorships of Plato and Xenophon were conceived and begun, to be continuously expanded until their respective deaths in 347 and c. 355 BCE. Xenophon almost created a new genre every time he started writing - the war memoir, the biography, the Socratic dialogue (perhaps already begun by Plato), the technical treatise, the political treatise, the fabricated biography (Cyrus) and others. The massive output by the philosopher Democritus and the physician Hippocrates must at the latest also belong to this period, although many of their writings can have been composed already from c. 430 BCE onwards. There are other Athenian authors who certainly belong in the beginning of the fourth century, for example Lysias the speech-writer and Isocrates the orator and pedagogical theorist, but it is important to note that the vast expansion of the volume and remit of prose books was not confined to Athens. Two decidedly non-Athenian treasures are lost, but they belong to these decades without a doubt: one is the works of the Greek physician and historian in Persian service, Ctesias, who authored several treatises, an account of India and a 23-book history of Babylonia, Assyria and the Persian Empire down to 398 BCE. The other is by Philistos, an influential Syracusan aristocrat, who began writing a comprehensive history of Sicily when he was exiled in 386 BCE, a work that was praised in Antiquity. 
Figure 1 should not be read simply for the significant conglomeration of prose authors around 400, but also for the volume and variety that hide behind the names. The full register of prose genres, ways of writing, domains of knowledge and sheer number of papyrus rolls (voluminous works intended for copying) presents a striking break-through in these decades. One possible book by Anaximander (c. 550 BCE), one or two by Hecataeus (c. 500 $\mathrm{BCE}$ ), and one by Anaxagoras (c. 450 BCE) may all have been exciting experiments in their own right, but they had nowhere to go, and they certainly did not create any new space or dynamic of reading. The book culture and the »librarization « that comes after Herodotus and the sophists is essentially different. ${ }^{33}$ By c. 380 BCE we have reached a point of no return, a critical mass when books have become an elite habit instead of a curiosity (cf. the quote from Plato above).

Apart from the technical side and the advantages of collecting (syngraphein), storing and retrieving stories, philosophy, medicine etc. in rolls, can we get any closer to the human momentum injected into this new technology? Tomas Hägg writes perceptively about one of the main figures of the Greek prose turn, Xenophon: "Now, Xenophon's choice of Agesilaus [as the object of a biography] was no accidental decision - the Spartan king had been his own patron and benefactor since the 390s BCE - nor was his purpose solely to establish a model for imitation. He had embarked on the Memorabilia to defend Socrates's memory in a current war of pamphlets, and he presumably composed his Anabasis in reply to another work that played down his own role in the Persian expedition. By the same token, he was now moved to write an apology of Agesilaus against what looks like an ongoing campaign to belittle the king's achievement. ${ }^{34}$ The fact that the elite turned to the writing and reading of books as a new means of positioning themselves is a significant part of the story. Aristocratic pamphleteering is also key for a new prose dynamic when we turn to Rome.

\section{Latin}

In Latin the same expression for prose-writing is used as in Greek: conscribere "to write together", or, alternatively, componere, "to put together «. ${ }^{35}$ It reflects the same basic idea that prose consists of many parts, whether imagined as already written in small parts or simply elements of speech or thought. A book, or even shorter pieces like laws and letters, are "put«or "written together", which involves, in modern terms, both careful or artful formulation and the addition of a textual structure. Our word, "prose", is of course also Latin, pro(r)sa oratio ("straightforward speech/discourse«), but this expression was only coined in the early imperial period (first attested in Seneca and Quintilian, 60s and 90s CE) and does not belong to the period of the emergence of Latin prose. ${ }^{36}$

33 Cf. Moretti, Graphs, Maps, Trees, 5, for a similar quantitative/qualitative turn in the spread of the modern novel: »And at this point [when a new novel is published every week], the horizon of novel-reading changes. As long as only a handful of new titles are published each year, I mean, novels remain unreliable products that disappear for long stretches of time, and cannot really command the loyalty of the reading public; they are commodities, yes but commodities still waiting for a fully developed market."

34 Hägg, Art of Ancient Biography, 42.

35 Both are attested also for writing poetry together, conscribo often used for shorter non-book texts, conscribo tabellas. Cf. dictionaries, Thesaurus Linguae Latinae, Lewis and Short.

36 The expression oratio soluta (»unbound speech«) was also used as opposed to poetry (carmen), but this could equally well characterize a looser style of prose as opposed to rhythmic prose. 
In Rome again we encounter a long period, of about a hundred and fifty years, completely dominated by various kinds of poetic writing, including drama, before real continuous prose in books is attested. This period overlaps almost precisely with the long century that comprised the Punic Wars (264-146 BCE) and which was crucial both for the dominance of Roman power as well as for the development of Latin literature. The two are obviously connected as (from the Roman point of view) the shock of Hannibal's invasion, the heroic mobilization and ultimate triumph are prominent elements of the cultural memory expressed by the early epic poets and playwrights.

In recent years a highly interesting discussion has emerged about the ultimate reasons and contexts for the rise of literature in Latin, a discussion in which scholars like Thomas Habinek, Dennis Feeney, Joseph Farrell, Sander M. Goldberg, Peter Wiseman, and others in different ways have rebutted the longstanding nineteenth and twentieth century belief that any civilized people simply and gradually develop their own literary language and traditions. ${ }^{37}$ The chronology, and even the fact of early Latin literature was simply taken for granted with the wisdom of hindsight..$^{38}$ I shall not venture into this discussion here as it is mainly concerned with the poetic and dramatic-performative beginnings from the third and second centuries BCE (and their entirely oral origins in the sixth to fourth centuries). The following section will be confined to the period between the two towering figures of early Latin prose, Cato the Censor (»The Elder", 234-149) and Cicero (106-43). The overall chronology can be illustrated in this way (ritual texts and poets again in red, prose authors in blue, other writing in grey):

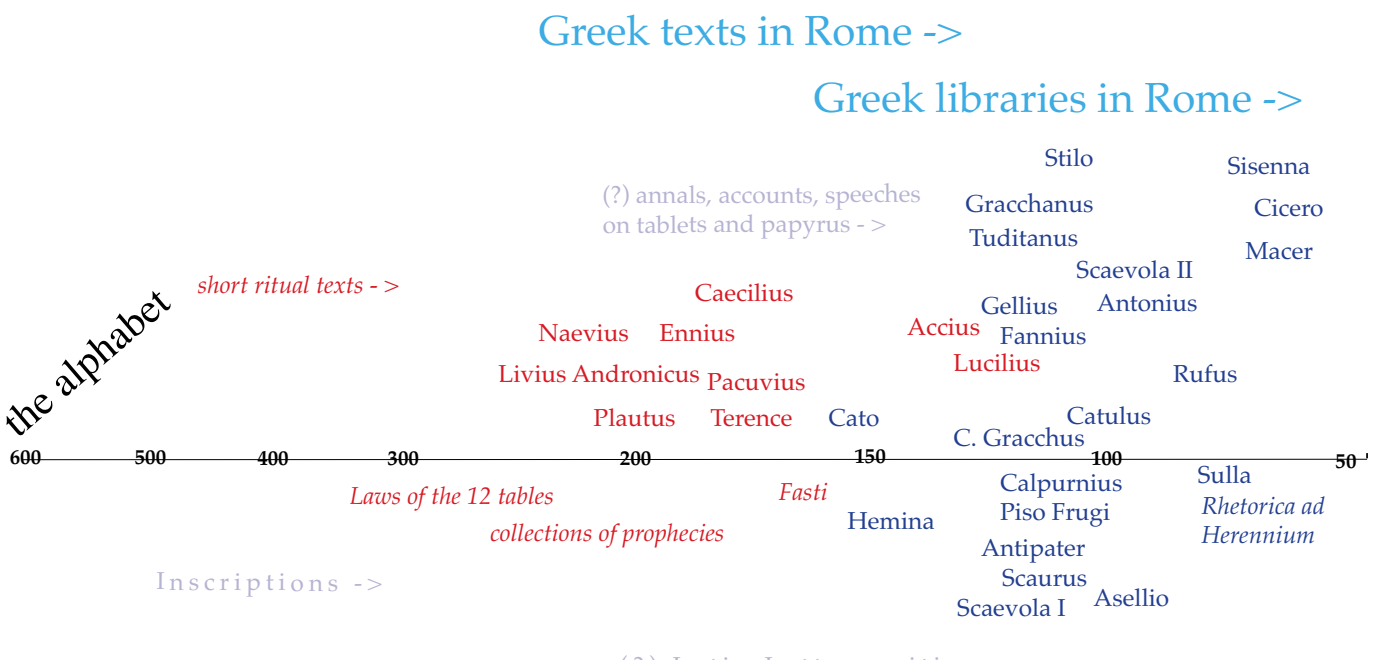

Fig. 2: Latin 60o-50 BCE

37 Farrell, Latin Language and Latin; Habinek, World of Roman Song; Feeney, Beginnings of Roman Literature; Goldberg, Constructing Literature in the Roman Republic; Wiseman, Unwritten Rome and Wiseman, Roman Audience. 38 Cf. Goldberg, Early Republic, 16. 
The early contact with Greek and Etruscan culture gave rise to the Roman alphabet and to inscriptions, short ritual and legal texts (probably on many materials), but, for a very long time, not to books in Latin. ${ }^{39}$ And when longer poetic texts were composed and written in books, beginning with Livius Andronicus, Naevius and Plautus, the performances were at the centre, the written texts mainly an aid. The theatre companies kept their own texts and there was no idea of a public or private archive or library to which they might ultimately belong as part of any canon. ${ }^{40}$ This was similar to the compose-use-discard habits of early Greek drama, and with the same result that very little has survived. Looking at the entirety of early Latin literature, we should not imagine a series of works from beginning to blossoming which obeyed the same rules of composition, storing, and dissemination. Just as with the Greek case in Havelock's analysis, what to us is a neat series of works of literature next to each other on the shelf or listed in a literary history, hardly belonged at that time to the same category at all. An important feature in this chronology is the circulation of Greek books among the Roman aristocracy from the second half of the third century, and the acquisition of entire Greek libraries, most famously the Macedonian library after the battle of Pydna in 168. This framework helps us to understand why Roman senators wrote prose in Greek through around half a century before Cato introduced prose writing in Latin (Fabius Pictor and others).

There is both a clear modern and an ancient consensus that Cato created or invented Latin prose. In his late rhetorical dialogue Brutus (46 BCE), Cicero offers a rich narrative of the history of roman eloquence in which Cato is the early watershed figure (Brutus 61-96), but framing the story in which Cicero himself is cast as the culmination. Cicero does have opinions about speeches before Cato, but most of this probably derives from orally transmitted reputation, indirect descriptions (e.g. from Roman historiography in Greek), and so on. It cannot be ruled out that earlier senators drafted speeches on tabulae, but Cato is treated as the first whose speeches could be studied, and Cicero specifically mentions that he managed to collect 150 of them (Brutus 65). Cato therefore was probably the first to edit and transmit his own speeches in books. ${ }^{41}$

This link between Cato's rhetorical self-fashioning and papyrus books recurs clearly in his (now mostly lost) Origines, the ground-breaking late ethnographical and historical work in seven books which took the narrative of Roman history down to $149 \mathrm{BCE}$, the year he himself died at the advanced age of 85 . In this first Latin book of Roman history (on the earlier Annals see below) he seems to have pursued several ideas consistently: one was to describe both Rome and other cities and societies (e.g. Carthage) by origin stories and cultural characteristics, another was to emphasize the role of the Roman people in the Punic Wars at the

39 While the immigrant story of the first Latin poets and playwrights has received attention (e.g. Sciarrino, Cato the Censor), the question of why this did not already happen a century or more before with massive contacts with the Hellenized world, has not been dealt with to the same extent. I owe to Christian Høgel (personal communication) the simple imperialistic point that once the Romans had Greek theatres, gymnasia, poets, intellectuals, books, etc. within their own territory, the question of appropriating (or discarding) this culture took on an entirely new urgency. This happened for Sicily and southern Italy during the First and Second Punic Wars and, of course, for Greece itself after 168 BCE.

40 Suerbaum, Archaische Literatur, 222; Goldberg, Early Republic, 17; Wiseman, Roman Audience, 48; cf. Suerbaum, Archaische Literatur, 250 on the canonization of Terence "In der Gracchenzeit beginnt die literarhistorische Würdigung « and the implications (3) below for poetic literature.

41 Von Albrecht, Geschichte der römischen Literatur, vol. 1, 317. Cf. Narducci, Cicerone e l'eloquenza romana, 111. 
expense of singling out great men; but he still made room for his own spectacular career, as a military leader, magistrate (consul and censor), politician, moral landmark and orator (a number of his own speeches were included) - in other words, a strong autobiographical statement.

The Origines was merely the culmination of a sustained effort of generating and transferring knowledge into Latin books. Cato was an avid consumer of Greek literature on all kinds of topics and his alleged disdain for some parts of Greek culture did not stop him from being inspired to launch an entire Latin prose book programme. ${ }^{42}$ We know of a lost treatise on warfare (De re militari) and of a series of didactic works written for his son Marcus. ${ }^{43}$ These didactic works probably resembled the only surviving book by Cato, the treatise on agriculture (De agricultura), in their raison d'etre that systematic knowledge in all these practical fields should engage with and express actual Latin practices, conceptualisation and usage instead of taking a detour around Greek equivalents. The advice contained in these books was designed to systematize and extend already existing communication with subordinates in the military campaign or in the fields - hence the seamless linguistic interface. ${ }^{44}$ This still does not explain Cato's new idea of transferring Latin knowledge into books, nor does it elucidate why Cato wrote the Origines in Latin as such an account might still be better written in Greek, and find more readers even among Roman senators.

A recent book by Enrica Sciarrino, Cato the Censor and the Beginnings of Latin Prose: From Poetic Translation to Elite Transcription attacks the problem from a novel theoretical angle but still expands on the widely accepted comparison between the two champions of Latin prose, Cato and Cicero, and their status as outsiders (homines novi). Although both noble and wealthy, their different sense of having to earn honours and careers through hard work pervades and inspires their attitude as conveyors of written knowledge. Their books become, in Sciarrino's phrasing, an additional embodiment of their virtue. ${ }^{45}$ As the title of her book shows, she also strongly links Cato's style and his embodiment of ritualistic speech and poetry to his new prose; in fact more than half of the book is concerned with analysing poetic and dramatic works as a context for understanding Cato. These links were no doubt strong and they illuminate the social and poetic, linguistic and ritual framework of Cato's efforts; one may add that the ultimate reasons for his choices will of course continue to elude us. From a book-historical point of view Cato did not exactly "create «Latin prose; one could perhaps use the less elegant but more precise phrase that he extended and regimented certain registers for writing in books. Alternatively, one could claim that he launched an imaginative experiment: what if we Romans actually had a standard of writing and a library for books in our own language? His experiment did not catch on right away.

Apart from Brutus, concerned only with rhetoric, there is a passage at the beginning of Cicero's On the Laws (De legibus) which is key for our appreciation of the period of prose between Cato and Cicero's own time, and it is worth quoting in full. In the opening dialogue, Cicero's friend Atticus is presented as urging Cicero to take up history writing:

42 See the balanced view already in Astin, Cato the Censor, $157 \mathrm{ff}$.

43 Suerbaum, Die Archaische Literatur, 409-413; Von Albrecht, Geschichte der römischen Literatur, vol. I, $317-319$.

44 A phenomenon which is similar to the early law codes written in many medieval vernaculars: the actual wording of oaths, punishments, economic entities etc. was so important for their validity that extra effort was taken to put the unstandardized vernacular language into writing.

45 For Cicero the extra complication was that, in marked contrast to Cato, he did not have military clientele or virtue; see Dugan, Making a New Man on Cicero's anxious compensation through texts and cultural ideals. 
Therefore take up the task, we beg of you, and find the time for a duty which has hitherto been either overlooked or neglected by our countrymen. For after the annals of the chief pontiffs, which are records of the driest possible character, when we come to Fabius [Pictor], or to Cato (whose name is always on your lips), or to Piso, Fannius or Vennonius, although one of these may display more vigour than another, yet what could be more lifeless than the whole group? Fannius' contemporary, Antipater, to be sure, blew a somewhat more forceful strain, and showed some power, though of a rough and rustic character, lacking in polish and the skill that comes from training; nevertheless he might have served as a warning to his successors that they should take greater pains with their writing. But lo and behold, his successors were those fine specimens, [Gellius, ${ }^{46}$ Clodius and Asellio! These two are not to be compared with Coelius [Antipater], but rather with the feebleness and clumsiness of our earlier historians. And why should I even mention Macer? His long-winded style shows indeed some little acumen (though borrowed not from the Greeks' wealth of knowledge, but from the Roman copyists), but his speeches contain many absurdities, and his elevated passages are exaggerated beyond all bounds. His friend Sisenna has easily surpassed all our other historians up to the present time, with the exception of those whose works may not yet have been published, and therefore cannot be estimated. Yet he has never been considered an orator of your rank, and in his historical writing he has an almost childish purpose in view, for it seems that Clitarchus is absolutely the only Greek author whom he has read, and that his sole desire is to imitate him. And even if he had succeeded in this, he would still be considerably below the highest standards. Therefore this task is yours; its accomplishment is expected of you, that is if Quintus agrees with me. ${ }^{47}$

Obviously a large host of historians between Cato and Sisenna, who wrote in the 70s, were at Cicero's disposal, but none of these are household names today. Except for some quotations, their works are all lost, and on our shelves Latin historiography begins with Caesar and Sallust in the 40 s and 30s BCE. A brief overview of these names with some additions displays a significant pattern (see figure 2 above).$^{48}$

In the midst of the political struggles within the nobility of the 130s and 120s BCE were the brothers Tiberius and Gaius Gracchus, both assassinated for their agenda of land distribution running against traditional interests of most of the nobility. Both were known orators, and Gaius Gracchus had his speeches from the later years written down and circulated. He also wrote what has been taken to be a historical and/or autobiographical piece..$^{49}$ One adversary of the Gracchi, Gaius Sempronius Tuditanus (consul 129) and one supporter, Marcus Junius "Gracchanus", both wrote long treatises on constitutional law each defending their position in the 120s BCE (Libri magistratuum and De potestatibus, the first works of their kind). ${ }^{50}$

\footnotetext{
46 Not in the Loeb translation, but inserted here from Ziegler's edition of De legibus.

47 Cicero, De legibus I.6-7, trans. Keyes.

48 The ancient references are collected in Suerbaum, Die Archaische Literatur, and Cornell, Fragments of the Roman Historians, gives a full exposition.

49 Candau, Republican Rome, 133, finds the evidence too weak for an autobiography.

50 Suerbaum, Archaische Literatur, 568, 572.
} 
Returning to Cicero's list, the first to be mentioned is Lucius Calpurnius Piso Frugi, a nobleman and senator, consul in $133 \mathrm{BCE}$ and censor in 120 BCE. He belonged to the conservative faction opposed to the Gracchus brothers, published speeches and wrote Annales in seven books, probably like Cato and many others, late in life, so possibly in the 120s BCE, but probably in the 110 s BCE. They might have gone down to $112 \mathrm{BCE}$, and his historical writing seemed to have had a self-apologetic tone..$^{51}$

Fannius was originally allied with the Gracchi, but at the second crisis and as consul in 122 BCE he turned against the remaining brother, Gaius Gracchus. His historical work belongs to the period after the death of Gaius Gracchus in $121 \mathrm{BCE}$ and it brought the narrative down to at least 129 BCE..$^{2}$

The next on the list, Vennonius, is very poorly attested, but can probably, from his place in Cicero's text, be considered contemporary with Piso and Fannius. Coelius Antipater is a much better known entity, as his lost monograph on the Second Punic War is often referred to by Cicero and also by Livy. Antipater may be the first professional intellectual in the list: he was known for his legal and rhetorical expertise as well; he never held office, but had ties with key people like Gaius Gracchus, Lucius Crassus and another non-noble intellectual attached to senatorial circles, the grammarian Aelius Stilo (see below). The dating of Antipater's History to the 110s BCE is fairly secure as it must have been finished after 121 BCE (due to its reference to the death of Gaius Gracchus). ${ }^{53}$

Gellius is an elusive figure, but he appears to have compiled - according to the best estimate probably in the 120 s $\mathrm{BCE}^{54}$ - an enormous Roman history from the origins to his own day in at least 97 books. Cicero next mentions Clodius who is identified with Claudius Quadrigarius, a contemporary of Sisenna whose history included the time of Sulla, and then Sempronius Asellio who follows the pattern of a nobleman writing contemporary history in his old age. We know that Asellio took part in important campaigns as a young man in the $130 \mathrm{~s}$ BCE and wrote about them, but in a work that also included a reference to events in 91 BCE. The final name dropped by Cicero is the hapless Licinius Macer, a contemporary of his and a political enemy; Macer's equally lost History of Rome also seems to have favoured his own family, the Licinii. ${ }^{55}$

The passage from The Laws only focuses on historians, and it is important to supplement the picture with some other prose writers to fully document the breadth and creativity of those final decades of the second century.

In one group there is more aristocratic pamphleetering and self-promotion. At the very centre of Roman politics in this period we find Marcus Aemilius Scaurus (163/62-c. 89 BCE), consul in 115 BCE, censor in 109 BCE and appointed leader of the senate (princeps senatus). Some of his speeches circulated in written form and he composed a remarkable political autobiography in the first person (De vita sua) possibly completed just after the consulship, perhaps later or updated later. ${ }^{56}$ Like almost everything else from this period, it is lost, but

51 Suerbaum, Archaische Literatur, 422; Cornell, Fragments of the Roman Historians, 230-239.

52 Suerbaum, Archaische Literatur, 426; Cornell, Fragments of the Roman Historians, 247-248.

53 Cornell, Fragments of the Roman Historians, 257.

54 Cornell, Fragments of the Roman Historians, 253-55.

55 Schanz and Hosius, Geschichte der römischen Literatur, 320.

56 Cornell, Fragments of the Roman Historians, 269; Suerbaum, Archaische Literatur, 442, puts its publication at the very end of his life. On Scaurus and his writings cf. Candau, Republican Rome, 133-139. 
through other authors we can glimpse the combative apologetic style of an influential man with many political enemies who often dragged him to court (politics were as a matter of course conducted through legal cases). In any case the move from a history of Rome with special emphasis on the author and his family to a straightforward autobiography shows the vitality of prose writing at this juncture. The most famous of these extensive lost political autobiographies would be that of the general and dictator Lucius Cornelius Sulla (c. 138-78 BCE) towards the end of our period. He completed it in his last years, but not from a sudden confessional urge - instead he was continuing a tradition of defending his and his family's honour which was probably initiated by Scaurus.

Add to these a hero from the pages of Cicero, Quintus Lutatius Catulus (c. 150-87 BCE), consul in 102 BCE and an ally of Marius until he sided with Sulla in 88 BCE and committed suicide in $87 \mathrm{BCE}$ after the Marian party had regained Rome. In the words of T. J. Cornell: "Catulus was an extremely important figure in the literary and intellectual history of the late second and early first centuries $\mathrm{BC} \ll{ }^{57}$ In fact he was a leading general, politician, patron, poet, promoter of Greek literature, and, most importantly in our context, he wrote speeches as well as a self-promotional treatise $\mathrm{On}$ his Consulate and His Deeds (De consulatu et de rebus gestis suis). The latter focused on the campaign of the year 102/101 BCE against the Cimbrians; its main point was to establish his heroic role in the decisive battle of Vercellae, from which the co-consul Marius had harvested most of the glory. ${ }^{58}$

In the same timeframe and political environment, an opponent of Scaurus, Publius Rutilius Rufus (c. 155-75 BCE), also resorted to writing in order to justify his actions. He had a long military career, was consul in 105 BCE, but lost a court case in 92 BCE which forced him into exile in Asia Minor. There he wrote a long autobiography, like Scaurus's in the first person. The rationale of writing this, far from Rome, could only have been an idea of circulation and preservation among leading Roman circles and book collections. Rufus can serve here as a link to the second group of prosaists, of a more intellectual or professional type, because he was known for his stoic allegiance and his position as a major expert on law. ${ }^{59}$

Rufus had studied law with Publius Mucius Scaevola (Scaevola I, c. 175-115 BCE), the Pontifex Maximus from 130 to 115 BCE. According to Cicero and others, Scaevola took the important step, after $130 \mathrm{BCE}$, of transferring the pontifical annals from disparate wooden tablets into 80 (papyrus) volumes..$^{60}$ If the assessment by Michael von Albrecht is valid, this in effect ended the tradition of pontifical annals and inaugurated that of literary historiography, and this link between a new medium of storage and new ways of writing would tie in well with the book-historical dynamics in the period argued for here. ${ }^{61}$

57 Cornell, Fragments of the Roman Historians, 272.

58 On Catulus see Candau, Republican Rome, 147-154.

59 On his intellectual side, cf. Candau, Republican Rome, 139-147.

60 Suerbaum, Archaische Literatur, 353; but this is subject to dispute, cf. Cornell, Fragments of the Roman Historians, 141-159.

61 Von Albrecht, Geschichte der römischen Literatur, I, 299: "Mit Scaevola endet die Tradition der Pontifikalannalen; an ihre Stelle tritt von nun an die literarische Geschichtsschreibung. « Similarly Musti, Il pensiero storico romano, 192. 
The son of the pontifex, Quintus Mucius Scaevola (Scaevola II, c. 140-82 BCE), consul in $95 \mathrm{BCE}$ and also Pontifex Maximus from $89 \mathrm{BCE}$, was the first great compiler and commentator on Roman law: his eighteen books of Civil Law is probably the product of his later years, in the 90 s or 80 s BCE.

An intellectual from the equestrian order of great importance in the history of literature is Lucius Aelius Stilo Praeconinus (c. 150-90/85 BCE), grammarian, philologist, the dedicatee of Coelius Antipaters History of the Second Punic War and teacher of both Cicero and Varro. Stilo wrote speeches for noblemen, but more ground-breaking was his interest in the remains of old Latin: he studied and commented on the Comedies of Plautus and analysed the language of the Law of the Twelve tables, old ritual songs etc. His was the first codification and canonization of poetic, legal and ritual works that might otherwise have been entirely lost.

A final entry in this group is Aurelius Opillus, a freedman teacher and writer who was active c. 100-75 BCE, partly in Rome, and partly in Smyrna in the entourage of the exiled (and just discussed) Rutilius Rufus. He wrote a philological miscellany in nine books called Musae, which, similar to Stilo's writings, collected, canonized and commented on pre-prose monuments of Latin.

It has been necessary to go through these normally obscure Roman aristocratic and professional writers in some detail in order to make the case for a sudden success of prose. The success was not achieved by Cato, and with the exception of Lucius Cassius Hemina's four books of Annales from the $140 \mathrm{OSCE},{ }^{62}$ his experiment was isolated and might well not have turned out to break new ground.

What stands out is the quantitative and qualitative leap in the period c. 130-90 BCE, reaching a point of no return before the age of Cicero, but one that has been invisible in literary history: literary scholarship has considered prose as already well established by Cato. We may add that a further reason for this oversight is that lost authors and writings make poor chapters in literary history. Indirectly, Sander Goldberg comes close to the view presented here, but without reference to any prose after Cato as he is dealing only with poetry: »It took the joint effort of writers and of men of letters to ensure that by the time of Sulla there was an ample stock of texts to read, to value, and to call by the name of literature. ${ }^{63}$ Otherwise, such readership of Latin literature is usually taken for granted only in the mid-first century BCE. This is what comes across indirectly in the great multi-volume literary history with special emphasis on production and consumption, Lo Spazio letterario di Roma antica, and other literary histories as well: the lost writers of the decades c. 130-90 are only mentioned as obscure forerunners of separate genres that would later flourish. In a book on Cicero and the publication of speeches, Emanuele Narducci states that this expansion of readership only happened in the age of Cicero; however he does acknowledge in a footnote that the last decades of the second century formed a certain prelude to this. ${ }^{64}$ But if all these prose works from the period are seen together across genres, three features stand out: (1) aristocratic self-fashioning in writing; (2) a short time span for the emergence of a vast prose literature; and (3) the expansion of the domains of knowledge covered by Latin books (jurisprudence, grammar, commentary, editions, history, autobiography, speeches, rhetoric).

62 Or from c. 150, cf. Cornell, Fragments of the Roman Historians, 219-223.

63 Goldberg, Early Republic, 29.

64 Narducci, Cicerone e l'eloquenza romana,158, n.6: "Probabilmente un certo allargamento del pubblico potenziale si era avuto a partire dagli ultimi decenni del II secolo, come dimostrano tra l'altro le allusioni all'esistenza di una pubblicistica politica di Gaio Graccho.» 
While the success of books in Latin can hardly be fully explained by a specific political environment, the aristocratic power game did constitute an important framework around the new habit of writing and circulating prose works among senators, their families and retinues. In the context of the history of the historical drama, the period has recently been described in these terms by Patrick Kragelund: ${ }^{65} »[\ldots .$.$] leading politicians had, from the late second$ century onwards, begun to adopt new, ever more aggressive methods of self-promotion, with memoirs and commentarii, epics, dedications, paintings, reliefs and statues celebrating their res gestae in ways that repeatedly went far beyond what had hitherto been considered appropriate. «Once this dynamic spilled over into writing in the vernacular instead of Greek, it quickly proved unstoppable. But as in the Greek case, critical mass was reached via a fortuitous route, not through a steady increase over a century. The first experimenters, such as Herodotus and Cato, wrote long prose texts into a non-existent space of private book collections and reading habits. Nor did they did create this space: it was formed suddenly and unpredictably by a network of people within a short time span.

There is a fundamental difference, of course, between the Greek and the Latin case: most Romans interested in books had access to an immense body of literary, scientific, technical and philosophical writing in Greek. This helps to explain why the transfer of all domains of knowledge into Latin took much longer than their original establishment in Greek books (philosophy, medicine, geography and more were only gradually added in Latin): the Greek Library served perfectly well in many domains for specialists and intellectuals and retained its authoritative status among educated Romans. We can observe the same long process in the Middle Ages when the vast authoritative body of Latin learning and literature continued to play the same role, even when written vernaculars like French and Old Norse had established themselves as literary channels and fields in their own right.

\section{French}

Latin continued to expand its domain throughout the imperial age, most importantly by adapting Christian literature and learning; with the Christianisation of the Empire Latin became the all-dominant learned and imperial language of the West, easily outlasting the Empire itself. As both the medieval literatures we are concerned with here, French and Old Norse, emerged in the twelfth century through the work of clerical authors who drew heavily on Latin writing, and as both literatures flourished in the thirteenth century and continued to live alongside a much more voluminous Latin book culture, we cannot ignore, as is usually done in language-based literary history, what this Latin framing meant for the emergence and success of vernacular prose.

The pervasive and continuously growing presence of authoritative books in Latin included, at the centre, the Sacred Scriptures themselves; most books of the Latin Bible were, since their canonization in Late Antiquity, perceived as continuous prose texts, which created a framework for Latin prose. But it took many centuries of book culture before non-Latin prose was actually written on the Continent (Irish and Anglo-Saxon were the exception, and in the early Middle Ages even these produced comparatively few continuous prose texts apart

65 Kragelund, Roman Historical Drama, 64, cf. also 57. 
from law codes, legal writing and adaptations from Latin). ${ }^{66}$ What did happen in the half millennium between c. 600 and 1100 was a steady growth of Latin prose texts, which were composed like sediments around the Scriptures: commentaries on the Bible and the church fathers, history writing conceived as updates or extensions of biblical history, theological treatises, liturgical and hagiographical compositions, accumulations of canon law etc. When this heavy textual "grounding" in and around the Scriptures was eventually broken in the twelfth century, both in new Latin writing and in new vernacular experiments, it is difficult to say whether the accumulated traditional, mostly monastic, Latin writing impeded or inspired the process ${ }^{67}$ But the important fact remains that numerous authoritative prose texts in Latin, of argumentative, collective and narrative kinds, were available and set prose books higher on the hierarchy of learning than in the Greek and Roman schools of antiquity where epic and dramatic poetry enjoyed a special status (although teachings by philosophical/religious school founders entailed the same authority for their followers as did theology in the medieval world).

In Italy some of the new Latin writing specifically theorizing prose emerged as early as the end of the eleventh century in the context of the Investiture Struggle, a new legal culture, and the steadily growing cadre of lay notaries. ${ }^{68}$ The art of letter and treatise writing was theorized in the body of literature on ars dictaminis and peaking in the twelfth century; its practice became highly influential in almost all of Latin Europe, beginning in the thirteenth century ${ }^{69}$ Here it suffices to note that in the same decades around 1200 when French and Old Norse prose take their significant quantitative leaps, there is a lively discussion about prose writing among ars dictaminis teachers in France and Italy, and in general an avalanche of writing in the arts, and in law, medicine and theology flowing from the first university environments forming in Bologna, Paris, Oxford, Naples etc. ${ }^{70}$ While one should be careful not simply to claim direct connections between the Latinate world of university teachers, lawyers, notaries, chanceries etc. on the one side and the emerging vernacular reading habits of aristocrats on the other, this general proliferation of books and book collections should be kept in mind as a broader framework.

Was there a ready-made definition and conceptualisation of "prose « in Latin during the twelfth and thirteenth centuries that the emerging vernacular literatures could lean on? Although the classical prosa (oratio) was available and used in some of the rhetorical and ars

66 The extraordinary translations into Old High German around 1000 by Notker Labeo of Boethius, Martianus Capella, the Book of Job etc. remained an experiment without consequences; on the disconnected nature of early German texts, cf. Müller, Gute Geschichte/n. See also »Implications« below.

67 On the move from this traditional "grounded « writing to new modes, cf. Mortensen, Comparing and Connecting. Cf. also chapter 3 "The Golden Age of Traditional Book Culture and the Birth of a New Book Culture« in Witt, Two Latin Cultures, 116-178.

68 Witt, Two Latin Cultures, 181-290.

69 Grévin, Rhétorique du pouvoir médiéval; Grévin, Les frontières du >dictamen<.

70 Witt, Two Latin Cultures, 384-397. 
dictaminis literature ${ }^{71}$ it was, surprisingly, still not yet the standard notion of the opposite of verse or poetry that it became in the later Middle Ages (from which the dichotomy was then bequeathed to us). It can be found also outside rhetorical literature,$^{72}$ but the main association of the Latin word prosa, probably until the fourteenth century, was actually liturgical, originating from a late antique distinction between classical quantitative verse and new rhythmic (and rhymed) verse (prosa): it referred either strictly to a sequence (sequentia) or more loosely to other types of chants; metonymically it would then also refer to the "story« or narrative of the saint praised in the chant, as in the common type of heading prosa de sancto/- $a$ etc. In medieval Latin we also find the expressions used in ancient Rome for writing a prose work, conscribere and componere ${ }^{73}$ Again these are not category-specific words but appear in many connections, including that of letter writing, poetry and so on.

In other words, the Latin vocabulary available for what we perceive as prose was quite loose and flexible. The case is the same in French where prose consolidated itself as the standard word in our modern sense only in the fourteenth century and after. ${ }^{74}$ What we meet in the first period of French prose writing are expressions like escrire, mettre en escrit, composer, combined sometimes with conte ("account", "narrative«), but these are also used for verse narratives. ${ }^{75}$ There is scholarly consensus that the first time prose is used in French is in Brunetto Latini's encyclopedia, Trésor (3.10), from c. 1265, and that before that the category was just referred to, if at all, as texts "without rhyme «. ${ }^{76}$

While the precise terminology only came later, the phenomenon of a sudden and voluminous narrative prose literature in French around 1200 has been a commonplace in scholarship at least since the 1950s. It can be visualized as in figure 3:

71 Most famously by Buoncompagno da Signa who gives the following definition in his treatise Palma (c. 1198, ed. Sutter, 106), claiming the priority of prose to poetry: Quid sit prosaicum dictamen. Prosaicum dictamen est oratio secundum libitum dictantis extensa nullisque metrorum legibus obligata. Vel prosaicum dictamen est ars, secundum quod est collectio preceptorum. Set non debet dici ars, immo artium mater, quia tota scriptura trahit originem a prosa. Nam rithmi et metra sunt quedam mendicata suffragia, que a prosa originem trahunt. (Partly quoted by Dembowski, Learned Latin Treatises in French, 258 and Spiegel, Romancing the Past, 57). Buoncompagno's disavowal of poetry is of course a way of selling his own goods as an expert in a certain prose style (cf. Witt, Two Latin Cultures, 384397 and the remarks below on Nicholas of Senlis).

72 As in Aldhelm (7th c.) and Bede (8th c.), see "prosa« in Dictionary of Medieval Latin.

73 Mittellateinisches Wörterbuch II, 1089, componere II.A.2.b = conscribere (liber bene conscriptus et bene compositus - litteras, chronicam composuit). Conscribere I.B.2 (=verfassen, componere) regulam conscripsit, sermones conscriptos Slavicis verbis.

74 »Prose« in Dictionnaire du Moyen Français (1330-1500).

75 "Escrire« and »mettre en escrit« in the prologue to Li fet des Romains (c. 1210; ed. Flutre and Sneyders de Vogel, 2), the latter also in the epilogue of Robert de Clari (c. 1215; La conqûete de Constantinople, ch. 120, ed. J. Dufournet, 212). "Conte« e.g. in the prologue to Philippe de Navare, Les Quatre ages de l'homme (c. 1265; ed. de Fréville, 1). Cf. also Anglo-Norman Dictionary.

76 Spiegel, Romancing the Past, 57; Armstrong and Kay, Knowing Poetry, 5-6. 




Fig. 3: French 950-1230

Again this graphic representation does not claim to be exhaustive, and in the period after 1200 more romances and other types of verse composition indeed appeared; but the chart does include the canonical works and illustrates the near absence of prose writing before 1200 and its abundance in the following decades. It covers literature in French irrespective of geography ${ }^{77}$ (and also mentions troubadour lyric in Occitan), and basically conforms to the pattern we have seen in antiquity: a very long period of complete dominance of poetic composition before a distinctive prose turn. One exception is the so-called Leis Willelme/Laws of William (the Conqueror) dating from c. 1130. One should perhaps not regard this as continuous prose - it is a list of brief laws - but in any case the impulse to take down short legal prose very early is recognizable from Greek, Roman, Nordic and other contexts. Such early written collections were reference tools for legal professionals/advisors/magistrates, and not made for a reading public. The other early appearances of prose are two biblical translations, the four Books of the Kings and Judges, and translations of some of Bernard of Clairvaux's Sermons - the first real attempts at continuous French prose known to us.

Otherwise, the chart displays in red all the highlights of French medieval poetry stretching from before the Song of Roland up to the early thirteenth-century Roman de la Rose. Most of these texts were based on Latin models. The first known works are adaptations into the vernacular of liturgical poems and saints lives, and in the twelfth century they are supplemented by Biblical paraphrases. Since the nineteenth century the texts considered great canonical pieces are those which do not rely directly on Latin models, such as the Song of Roland, troubadour lyric, Tristan, the verse short stories by Marie de France and the trend-

77 For a discussion of how to define French literature, see Gaunt, French Literature Abroad. 
setting Arthurian verse romances by Chrétien de Troyes. The verse Romance genre, however, also originated in the mid-twelfth century, first in a number of adaptations of Roman classical texts, the so-called Romances of antiquity (Roman d'Eneas, Roman de Troie, Roman de Thèbes, Roman d'Alexandre). In any case, almost all of these texts, including the Song of Roland and other chansons de geste, were penned by Latinate clerics. ${ }^{78}$

While it is tempting to characterize the new prose literature as a means of individual self-promotion by non-Latinate aristocrats - obvious in the case of the chronicles/memoirs by Villehardouin, Henri de Valenciennes, Robert de Clari and, later in the thirteenth century, Phillippe de Novare - in fact most prose texts are anonymous, either adaptations from Latin historiography or elaborations on the Arthur material. ${ }^{79}$

The chronicles deal with the history of Normandy and of France, with the Crusades, and with ancient Roman history. Among the earliest are probably the mostly neglected Geste de France and Chronique de Normandie. ${ }^{80}$ From the very large number of extant copies and versions, the most popular early prose texts seem to have been the Pseudo-Turpin chronicle on Charlemagne's legendary "crusade« against the Muslims in Spain, and the voluminous translation of the Latin History of the Kingdom of Jerusalem by William of Tyre, known as Éracles (Paris, around 1220). In volume, though not quite in popularity, these were soon matched by the enormous Lancelot prose cycle, consisting of Lancelot, Mort le roi Artu, La quete du Saint-Graal in different combinations and redactions. ${ }^{81}$ Add to this the prose Tristan and the continuations of Éracles (both begun around 1230) and the massive and much copied collections on Roman history from around 1210, the Histoire ancienne and Li Faits des Romains, and it is easy to see that the number of unique pages available for reading in French was disproportionately higher in 1230 than in 1200; more importantly, the number of books available in French (including copies of twelfth-century texts) must have been on an entirely different scale than in the twelfth century (see below, on verse romances). Copies of the new prose literature were made and circulated very widely with an epicentre in France and Flanders, but with readers and redactors in England, Normandy, Italy, Palestine and Cyprus. Some texts also spawned extensions, translations and imitations in Iberia, the Eastern Latin Empire, in the Western German Empire and Scandinavia. ${ }^{82}$ Thirteenth-century French prose writing remained, in a sense, "pre-Ciceronian «, as it was predominantly narrative and paratactic and "unlearned " in its style. ${ }^{83}$ With a few thirteenth century beginnings (including Jean de Meung's translations and Brunetto Latini's Trésor), it was in the fourteenth century - culminating with Nicole Oresme's (c. 1320-1382) translations of Aristotle - that French prose really began its extension into abstract vocabulary and complex syntax and was able to take over philosophical and scientific domains of knowledge from Latin. ${ }^{84}$

78 Cf. Gaunt, Retelling the Tale, 25-37.

79 Cf. Stempel, Anfänge der romanischen Prosa, 593.

80 The early versions were put together around or just before 1200 . I am grateful to Gregory Fedorenko for giving me access to his unpublished dissertation Texts, Manuscripts and Historical Significance.

81 Gaunt, Retelling the Tale, 71-92.

82 Éracles is perhaps the most European of these texts; for the wide dissemination see Handyside, Old French William of Tyre.

83 Cf. Stempel, Entwicklungsperspektiven des historiographischen Diskurses; Baumgartner, Le choix de la prose.

84 Baumgartner, Le choix de la prose, 16; Dembowski, Learned Latin Treatises in French. 
The sudden presence of a large amount of prose writing in the beginning of the thirteenth century has naturally attracted scholarly attention; it was already thematized in the work of Brian Woledge $(1953,1964)$, and later by Wolf-Dieter Stempel $(1972,1987)$ and Wlad Godzich and Jeffrey Kittay (1987). The question of its emergence became more focused with the ground-breaking work of Spiegel (1993), followed by a thematic journal issue in $\mathrm{Ca}$ hiers de recherches médiévales et humanistes edited by Baumgartner (1998): "Le choix de la prose.$^{85}$ More recently Gregory Fedorenko (2012) has returned to the general question while researching two forgotten early prose texts, and Adrian Armstrong and Sarah Kay (2011) have discussed the conditions of vernacular poetry after the rise of prose which - with a well-chosen metaphor - they characterize as the continued existence of black-and-white photography after the invention of colour reproduction.

Much of the discussion has been predicated on the acceptance of a claim made by Nicholas of Senlis, the first French translator of the Pseudo-Turpin Chronicle. Not only does he seem to be very straightforward, but his statement can even be dated to 1202, at the very beginning of French prose literature. ${ }^{86}$ I quote from Gabrielle Spiegel's English translation (p. 55-56):

I wish to begin the history of how the good Emperor Charlemagne went to Spain in order to conquer the land under the Saracens. Many people have heard it told and sung, but what these singers and jongleurs sing and tell is nothing but a lie. No rhymed tale is true [»Nus contes rimes n'est verais"]. Everything they say is lies, for they know nothing about it except through hearsay. The good Baldwin, the count of Hainaut, dearly loved Charlemagne, but he did not want to believe anything that was sung about him. Thus he had all the good abbeys of France and all the libraries searched to see if one might find the true history. ${ }^{87}$

This truth claim for prose has been taken, with few exceptions, as both sincere and as a testimony of a common attitude at the time..$^{88}$ The major concern of Nicholas, however, is to make sure that it is known that there is a book behind his account, not just a song. More importantly, we find outrageous truth claims in all kinds of writing from the twelfth and thirteenth centuries, poetic and prosaic, and in the vast spectrum between fiction and history ${ }^{89}$ Nicholas is positioning himself and his version of the story in relation to a certain type of oral entertainment, and, in the interest of lending authority to this one piece of writing, he is either exaggerating

85 No. 5, 1998; only a small part of the issue, however, discusses the early period.

86 On Nicholas and the context, see Spiegel, Romancing the Past, 61-65. His quotation is used directly by Godzich and Kittay, Emergence of Prose, 13-15, Spiegel, Romancing the Past, 55-56, Zink, Medieval French Literature, ch. 6.; Dembowski, Learned Latin Treatises in French, 258.

87 "Voil commencer l'estoire si cum li bons enpereires Karlemaine en ala en Espagnie par la terre conquere sore les Sarrazins. Maintes genz si en ont oi conter et chanter mes n'est si menconge non co qu'il en dient e chantent cil chanteor ne cil iogleor. Nus contes rimes n'est verais. Tot est mencongie co qu'il en dient car il n'en sievent rienz fors quant par oir dire. Li bons Baudoins li cuens de Chainau si area molt Karlemaine ni ne veut onques croire chose que l'om en chantast. Ainz fit cercher totes les bones abeies de France e garder par totz les armaires por saver si l'om i trouveroit la veraie ystoire ...« (B.N. fr. 124, fol. Lr, quotation from Spiegel, Romancing the Past).

88 Baumgartner, Le choix de la prose, is skeptical of identifying prose and truth very broadly on the basis of this one quotation, and Fedorenko, The Texts, Manuscripts and Historical Significance, 230, agrees that prose authority in Nicholas too is more about sources than form.

89 Often an invented book is called upon, most famously in the case of Geoffrey of Monmouth; cf. Agapitos and Mortensen, Introduction. Cf. also the quotation by Buoncompagno da Signa, above n. 71. 
or he is actually not drawing a modern distinction between prose and poetry; in fact he only speaks of rhymed tales (he may be thinking only of chanson de geste); he cannot be dismissing poetry in general. Latinate cleric that he was he would have been aware of the unassailable truth claims made in the highly popular contemporary Biblical epic (e.g. Petrus Riga), historical epic (e.g. Gauthier de Chatillon, Guillaume le Breton), or didactic theological poetry (e.g. Alain de Lille), not to speak of time-honoured Biblical epics like those of Juvencus, Sedulius and others, nor indeed of (rhymed) hymns, or the Psalter and the Song of Songs themselves. A similarly explicit and strong statement is even made about French verse a few decades before, namely by Guernes in 1174, stating in regards to his verse life of Thomas Becket: "Never before was such a good French poem made or invented. Made and corrected at Canterbury, there is not a single word that is not the truth. $\aleph^{90}$ Finally, Nicholas's position cannot be read as valid for the subsequent prose literature - which includes blatant fictions like the Lancelot cycle. ${ }^{91}$

In her Romancing the Past from 1993, Gabrielle Spiegel brought the discussion forward by emphasizing the political context of some of the new prose literature. Due to the successes of the French king Philip Augustus in acquiring Normandy in 1204 and in routing the English and imperial armies at Bouvines in 1214, the Flemish (and other) aristocrats on the losing side compensated culturally by "romancing the past « through this literature (with its supposedly stronger truth-claim). While this context makes very good sense for a number of texts, including some of the ancient history narratives in French, it still leaves out significant pieces of prose writing - some of which were connected to the French crown, like Geste de France and Éracles ${ }^{92}$ - from the crucial decades. There was a wider literary space in which many different political and cultural agendas could be played out in French prose. What literary and communicative framework was necessary to make prose writing this sudden success across a very widely spread aristocracy with French as their first or second language?

The larger framework is implied by Martin Aurell in his excellent survey, Le chévalier lettré - Savoir et conduite de l'aristocratie aux XIIe et XIIIe siècles. The dynamic that Aurell describes unfolds over two centuries in which the ruling warrior class of Western Europe assimilated book culture and some of the key values it expressed. This worked both ways: the entertainment, refinement and instruction that writers and performers provided, were extended, upgraded and developed by direct patronage (instead of indirectly through ecclesiastical institutions, one might say). Aristocratic ownership of books and book collections became one of the hallmarks of a more civilized ruling class (along with new fashions, refined manners, ideals of courtly love etc.). Not only did the knights and their female peers own books, they listened to them, read them, were instructed by their value systems and even sometimes dictated or wrote them. Such an intense exchange between the aristocracy and the world of books could not have happened without capitalizing on clerical Latinate culture - but also not without breaking its written monopoly and in the process, launching a number of vernacular literatures.

90 I quote from O’Donnell, Anglo-Norman Multiculturalism, 339.

91 Although they are in some ways packaged as history, cf. Burns, 1209?.

92 Cf. Fedorenko, Texts, Manuscripts and Historical Significance; Handyside, French William of Tyre. 
It is within this broader picture of aristocratic men and women embracing books that the prose turn of French between c. $1190 / 1200$ and c. 1230 should be placed..$^{93}$ Libraries outside ecclesiastical institutions are increasingly attested from the second half of the twelfth century; these are mainly royal or princely book collections or private libraries of high-standing clerics. ${ }^{94}$ These libraries still almost exclusively consisted of Latin texts, but the beginnings of vernacular books are to be found there too, at least in the later twelfth century as is proven by references in the verse romances. ${ }^{95}$ The most conspicuous concrete link between a princely Latin book collection and French literature in this period is that of the Count of Champagne, Henri le Liberal (1127-1181) and his wife, Marie (1138-1198), daughter of Louis VII and Eleanor of Aquitane. The library of the Count at Troyes was, according to the findings of Patricia Stirnemann, partly created on demand by copyists and artists working outside the usual monastic or episcopal setting - which would soon become the norm for thirteenth-century vernacular literature. It contained patristic learning, exegesis and more, and had a clear princely emphasis on historiography, ancient and modern (including Geoffrey of Monmouth). The library of Marie of Champagne, as a separate or added entity, is attested by the author Evrat who dedicated his French verse adaptation of Genesis to her (begun in 1192 but completed after her death in 1198), and who refers also to her reading habits. ${ }^{96}$ Her collection must at least have had copies of other French works dedicated to her, including Lancelot by Chrétien de Troyes. Stirnemann furthermore places a very early French prose work (c. 1180-1190) in her library - or at least in a noble library of the same character, period and region - namely a translation of some of Bernard of Clairvaux' Sermons. ${ }^{97}$

The correlation between the emergence of extra-ecclesiastical book production and storage and the first small aristocratic collections including works in French in the decades around 1200 is furthermore evidenced in a striking manner by a testimony from the Latin History of the Counts of Guines and Lords of Ardres by Lambert of Ardres; this work was composed between c. 1198 and 1206 and describes at length the illiterate and yet learned Count Baldwin II (1169-1206) and his library. The description ends by mentioning another lay person who had been converted to books:

93 The significant role of aristocratic women readers/listeners becomes more visible from the end of the twelfth century onwards (see below on Marie of Champagne), and is well documented especially for French and German literature, cf. Green, Women Readers, and Aurell, Chevalier lettré, 208-261. High-standing women may have played some or even similar roles in the Greek, Roman and Old Norse cases too, but this is poorly documented.

94 On aristocratic libraries, Aurell, Chevalier lettré, 106-114 and Stirnemann, Quelques bibliothèques princières. For a comprehensive survey of twelfth-century libraries in Latin Europe, Munk Olsen, Classiques dans les bibliothèques médiévales.

95 Duggan, Romances of Chrétien de Troyes, 44-46. Another good example is that of the poet Guernes, writing about Thomas Becket in French verse in 1174, as noted by Thomas O'Donnell, >The Ladies Have Made Me Quite Fat‘, 110, n.31: "Guernes himself testifies to the growing demand for vernacular books when he accuses scribes of circulating the early, uncorrected version of his work."

96 He refers to her »armaire« (book-cabinet), cf. Stirnemann, Quelques bibliothèques princières, 32. For a full account of the literary environment around Henri and Marie see Benton, Culture, Power and Personality.

97 Stirnemann, Quelques bibliothèques princières, 33-34. This work is distinct from the Old French translation of Bernard's Sermons on the Song of Songs, edited by Gregory; interestingly, they are both dated to the last decades of the twelfth century on palaeographical grounds (cf. Stewart's introduction, xi-xii), and thus confirm that a role was played by translations from Latin in the very first phase of French prose. 
"What more? He was rich with such an abundance of so many kinds of books, that he might be thought to rival Augustine in theology, Dionysius the Areopagite in philosophy, Thales of Miletus, the fabulist, in popular entertainments, and the most renowned troubadours in epic songs, whether the deeds of the nobles or even the fables of the common folk. If one had not seen and heard of it, moreover, who would believe that Hasard of Aldehem, who was completely a layman, learned letters and in an entirely lay manner was similarly made literate by Baldwin? The man I just called Hasard, indeed, while keeping and guarding the whole library of the count, read and understood all the books he had that were translated from Latin to French. ${ }^{98}$

These books and some of their translators are mentioned before this passage, including prose translations (one must surmise) of a commentary of the Song of Songs, a book of Physics (presumably Aristotle), a Life of St Anthony, the Polyhistor by Solinus and more. What we see, then, in the cases of Marie de Champagne and Baldwin of Guines is the extension of private Latin libraries already designed for a specific form of noble learning to include French works, much in the same way we can imagine some Roman aristocrats extending their private Greek libraries with the new phenomenon of Latin prose books. Patricia Stirnemann underlines that the existence of private noble book production and collection at Troyes and at Guines should not be seen as anomalies in the decades around 1200, and that similar aspirations could probably be found in Paris, Rouen, Sens, Reims, Amiens and other minor and major courts. ${ }^{99}$

While codicology, palaeography and records of library history usually give crucial support to fill the gaps in textual and literary history, I would argue that in this (as in the other three cases) the reverse can also be true: the prolific output of French prose texts in the decades c. 1190/1200-1230 is in itself a source of book and library history; to translate, compose and copy a large number of books made for reading (aloud and silently) ${ }^{100}$ in the vernacular indicates that such texts were destined for, and helped to create, new storing and reading practices. These were first attached to Latinate personnel and book collections in private aristocratic contexts; and as books in French went from being a curiosity in the twelfth century to becoming a habit in certain circles in the thirteenth, the road was paved for private collections consisting mainly of vernacular books in the later thirteenth and fourteenth centuries. ${ }^{101}$ While the documentation for this development is uneven, it is important to note that in spite of our lack of more contemporary library lists or securely datable and localised early book production in French, the dating and the ideological and social context of most of the early prose works are uncontroversial and therefore valuable for assessing aristocratic book collections from the period.

98 Lambert of Ardres, History of the Counts of Guines, ch. 81, 114-115. Baldwin of Guines is also discussed by Stirnemann, Quelques bibliothèques princières, 36-37 and Aurell, Chevalier lettré, 99-100.

99 Stirnemann, Quelques bibliothèques princières, 37.

100 Green, Medieval Listening and Reading, has convincingly shown how the late twelfth and early thirteenth century romances in German were destined both for reading aloud in groups and for individual reading - and that these results can be considered valid also for French romances; cf. Green, Women Readers, 7-23. Cf. also Duggan, Romances of Chrétien de Troyes, 34, who emphasizes the book-historical aspect: "But the primary mode of existence of the romance as we define it [...] was in manuscript copies." For a perceptive in-depth description of aristocratic reading in the private-cum-public space of the chambre, see Rector, En sa chambre. What he characterizes "as a fully articulated literate culture (88) for Anglo-French around 1150, however, I would, for quantitative reasons and for the absence of prose books, describe as the early beginnings of a new reading culture (see below on Chrétien etc.).

101 Aurell, Chevalier lettré, 109-110. 
One possible objection to this short dynamic phase I am arguing for emerges from comparison (also with Old Norse below): the development of French as a book language no doubt owes much to the success of the verse romances in the second half of the twelfth century. Such a phase stands out in contrast to the other cases where there is no similar long poetic narrative form meant for reading before the prose turn. Furthermore, the romances of Antiquity as well as those with Breton material by Wace and Chrétien de Troyes are very "bookish" texts: long and complex, either directly dependent on learned models or playing with them, and obviously works by Latinate clerics who had an eye on long-term library and intertextual fame. While this »run-up «phase to the prose turn might very well be considered a necessary preparation, there also seems to be the possibility that in the beginning these ground-breaking romances had a restricted impact, a more experimental status, and that their reception was mostly in connection with the specific environments in which they were composed and used for entertainment. What would have become of them if the thirteenth century expansion of aristocratic book culture had not taken place? The authoritative study of Chrétien by Joseph J. Duggan agrees that "The early thirteenth century is a crucial period in the history of reading. $\aleph^{102}$ While referring to the results of a complete mapping of the extant copies of Chrétien's romances (pp. 34-46), Duggan establishes that the earliest copy we know is from around 1200 and that many of the important manuscripts date from the first half of the thirteenth century. Furthermore, from around 1225, Chrétien's works begin to appear in combination with other texts and in larger volumes - a clear sign of canonization. Both scenarios are possible: either the prose expansion followed as a "natural«second phase after the verse romances had paved the way for an idea of long books in French, or the survival, canonization and proliferation of the verse romances (and their material) were basically due to the aristocratic book culture emerging in the decades after c. 1190/1200. ${ }^{103}$

\section{Old Norse}

Turning finally to the case of Old Norse, the terminology is somewhat unprecise again. The closest we come to a mot propre for writing prose is a cognate of the Latin componere: setja saman (put together) and it can be supplemented with bók and sqgu, to put a book or a story together (attested from the late thirteenth century). The much broader rita (to write) is of course often used as well in the context of writing books. The Latin prosa also turns up a few times as a loan word, but only in the main medieval meaning of a liturgical composition. ${ }^{104}$

The chronology of Old Norse literature is fraught with problems as so many texts are anonymous and devoid of clear historical references to their time of composition. Although some fragments survive from the twelfth century and a number of manuscripts from the early thirteenth century, the period of our interest here, most texts from this period have been transmitted only in copies from the second half of the thirteenth century and especially from the fourteenth century and even later. Many of the items presented below in figure 4

102 Duggan, Romances of Chrétien de Troyes, 44.

103 Cf. Würth, "Antikenroman « in der isländischen Literatur, 128, who emphasizes the importance for the prose versions of the fact that the material had been thoroughly dealt with by Chrétien.

104 Entries from Ordbog over det norrøne prosasprog (onp.ku.dk/; retrieved on 12 June 2017). On the terminology also Sørensen, Kapitler af Nordens, 170-171. 
are therefore placed in a chronology on the basis of scholarly consensus, such as it is, rather than on biographical knowledge or clearly dated references that were mostly the case in the previous three examples. ${ }^{105}$



Fig. 4: Old Norse 1100-1230

The illustration runs counter to all standard histories of Old Norse literature which invariably begin with the two main poetic forms: the Eddaic mythological and heroic poetry and the prestigious complex form of Skaldic poetry which always carried the skald's name. In some sense, then, Old Norse literary history complies with the general pattern that poetry precedes prose by a century or more. As we are presently concerned with the book-historical development, however, the old poetic forms are late as they only turn up when they are actually taken down in writing in the early thirteenth century, embedded in an already established prose reading culture: the Eddaic (and skaldic) poetry in Snorri's prosimetrical poetological anthology of the 1220 ("Snorri's Edda"/Prose Edda) and the (probably later) collection, the Poetic Edda (ms. c. 1275, but copied from an older exemplar), while Skaldic poems are quoted in sagas, beginning with the fragmentary Norwegian chronicle Agrip (c. 1190), and with an increasingly strong presence from the early thirteenth-century sagas and onwards in the later parts of the century (e.g. in Heimskringla, 1230/40s). ${ }^{106}$

105 The timeframes for some of the works are disputed. I rely mainly on Mundal, Introduction; Mundal, Sagalitteraturen; Würth, "Antikenroman « in der isländischen Literatur; Meulengracht Sørensen, Kapitler af Nordens litteratur; Wellendorf, Lærdomslitteratur; Andersson, Growth of the Medieval Icelandic Sagas; Andersson, From Tradition to Literature; Andersson, Partisan Muse; McTurk, Companion to Old Norse-Icelandic. I have included Fornaldarsagas (sagas of ancient times) in the table around 1220-1230 although they are only testified with certainty somewhat later; however, the earlier date of their origin has been generally accepted; Cf. Tulinius, Matter of the North; the hypothesis that they may have been preceded by lost Latin models further strengthens the view that Old Norse literature was clerical in its first phases; cf. Jensson, Earliest fornaldarsögur, and Lassen, Origines Gentium.

106 A few runestones before the age of books in the North contain short poetic inscriptions. 
What is sufficiently clear from the titles in the chart is how Old Norse book writing, like French, emerged with the work of twelfth-century clerical writers (in both Iceland and Norway) who took down law collections, and translated and adapted saints lives, theology, chronicles, etc. from Latin. ${ }^{107}$ Before addressing the apparent dynamic around 1200 , it is worth quoting the locus classicus about early twelfth-century learning. This comes from the so-called First Grammatical Treatise, dated to c. 1150 (though more safely within the range 1125-1175). This small work analyses the sound system of Old Norse in order to establish a systematic and workable orthography for the newly written language. From its clearly pioneering spirit, it is tempting to date it to the second quarter of the century. It opens with a broader picture of languages and alphabets:

In most countries men put into books either the great events that have come to pass within their country, or whatever seems most memorable that has occurred abroad, or men put their laws into books, each people in its own language. [He goes on to mention Greek, Latin, Hebrew as using different alphabets and English which adapted the Latin alphabet]. Now according to their example [the English], since we are of the same tongue, although there has been much change in one of them or some in both, I have written an alphabet for us Icelanders also, in order that it might become easier to write and read, as is now customary in this country as well, laws, genealogies, or sacred writings, and also that historical lore which Ari Thorgilsson has recorded in his books with such understanding wit. ${ }^{108}$

The passage is famous as it is the only one in the twelfth century which attempts to state what is available in writing in Old Norse. Laws are well attested to have been written in Iceland in $1117 / 18$, but most probably only in very few copies as reference for the legal specialists (law speakers). ${ }^{109}$ The »sacred writings « (Pýðingar helgar) could be exegetical works, or include the computistical, theological or hagiographical writing which is also attested around 1150 or slightly before. Finally, of the writings of Ari we possess versions of the very brief Book of Icelanders (Íslendingabók), a kind of shorthand chronicle.

It is therefore certain that some minor pieces of prose writing were available in Iceland before c. 1150, and perhaps also some law codes in Norway. But this was all on a very small scale, and can be characterized as a "scribe-writing-for-other-scribes " pattern, ${ }^{110}$ and also as a phenomenon which accompanied the major concerns of establishing a Latin scribal and

107 Cf. Mortensen, Den formative dialog; Wellendorf, Lærdomslitteratur.

108 First Grammatical Treatise, ed. Haugen, 13.

109 Hoff, Hadifli Másson, 379. The dates of the first written version of the Norwegian Laws of Frostating and Gulating cannot be established, but they are likely to be among the first books written in Norway. Helle, Gulatinget og Gulatingslova, dates the writing of the Gulating Law as early as around 1080, which in book-historical terms would be striking, the invention of Old Norse writing thus being contemporary with the advent of Latin literacy and decades before the oldest known writing in Iceland. The oldest manuscripts are from the early thirteenth century. Cf. Mortensen, Den formative dialog, 255-256.

110 Cf. Van der Toorn, Scribal Culture, 51, describing the culture of the Second Temple before the arrival of Hellenistic book culture (approximately the period c. 500-350), the environment where the oldest books of the Hebrew Bible were composed: »Moreover, the books that the scribes produced were not books in the modern sense of the term. They were not comparable either in form or function. Scribes wrote scrolls (rather than books) for the benefit of other scribes (rather than for private readers). A book market did not exist, nor were there public libraries; in fact there was no reading public of any substance.« 
clerical culture at the time. What happened around 1200 in the whole Old Norse realm was of an entirely different magnitude. The suddenness of this is sometimes acknowledged in Old Norse literary history, e.g. by Else Mundal:

Since we do not know the exact date for any of the sagas belonging to these genres [sagas of Kings, of Bishops, of early Icelanders [=family sagas]], we do not know for sure which of these genres developed first and the nature of the relationship between them. However, in any case, all these Icelandic genres devoted to Icelandic subjects developed during a short period of time. We are in fact talking about a phenomenon that can be described as a "literary explosion" in Iceland. ${ }^{111}$

Even if a very productive phase is acknowledged as setting in around 1200, the sudden success of prose has either been ignored or put in very different terms than those referred to above for Old French literature.

There have been several reasons for assuming a slow, gradual rise of the prose register in Iceland and Norway. First, the iconic status of the founding father of Icelandic literature, Ari fróði, had this effect. Although his known piece is modest and partly to be characterized as a list, it became canonical as a starting point for the historical saga writers a century later; this continuity was sanctioned by Snorri and others in the thirteenth century and has perhaps made literary historians overlook the actual gap in significant prose writing in the mid-twelfth century. ${ }^{112}$

Secondly, most scholarly energy has been directed towards solving the problem of the origin and characteristics of the most canonical literary genre, the Family Sagas (or Sagas of Icelanders/Sagas of early Icelanders), especially the question of the oral basis of the sagas as we read them today. These sagas are only just mentioned in the graphic overview above, and their written beginnings around 1230 (or slightly before) are not controversial. A few famous pieces are usually dated around here, like that of the warrior-poet Egil's saga, while the epic Njal's saga is usually located in the second half of the thirteenth century. Do they transmit a long oral narrative form relatively directly, or did the writing of the sagas contribute considerably both to the length and the complexity of such stories? Following the thesis of the so-called free-prose theory (the oral form was also supposed to have been long and complex) came the antithesis represented by the book-prose theory (positing strong authorial acts for the greatest and most complex masterpieces) ${ }^{113}$ and later, various differing syntheses of modern orality studies ${ }^{114}$ we are in a way back to square one where both the influence of writing is allowed, but so too is a high evaluation of an oral transmission of plots and modes of storytelling. But whichever position one takes in this debate, the general acknowledgement of the volume and quality of oral storytelling in Iceland over a long time invariably results in an assumption of long continuities as being necessary for understanding the emergence in writing of classical family sagas in the thirteenth century. Therefore no prose turn or new prose register has been needed to explain the blossoming of (all types of) sagas just after 1200.

111 Mundal, Introduction, 3.

112 For this point, cf. Mortensen, Nordic Medieval Texts.

113 Theodore Andersson's helpful translations of these terms are »traditionalist« and »interventionist« (From Tradition to Literature, 8).

114 Especially by Gisli Sigurdsson and Tommy Danielsson, cf. Andersson, From Tradition to Literature. 
Looking at the big picture in book-historical terms, however, there may still be a case for comparing the role of prose books in the early thirteenth century with the Old French scenario. Before c. 1190/1200 we can only observe small texts in the wake of the foundational acts of Ari fróði, the early laws and the First Grammatical Treatise. They are concerned with supporting the edifice of Latin Christian learning and story-world and probing only very tentatively into the new medium of a written vernacular. But in the three decades from c. 1190/1200 we suddenly have in Old Norse prose all of the following: voluminous translations of Latin chronicles (world history, Roman history, History of the Britons and of Troy), thick adaptations (and expansions) of Latin legends (of the two Olav's (Tryggvason and Haraldsson), of Thomas Becket, probably of Mary and more) and of Gregory the Great's Dialogues, massive volumes of Kings' sagas culminating in Snorri's Heimskringla, prose adaptations of Romances (Charlemagne, Tristan and more), the first batch of family sagas including probably the famous Egil Skallagrimson's saga, episcopal chronicles and more. And looking ahead just two decades further, to the mid-thirteenth century, we can include such different canonical prose masterpieces as Laxdæla saga and the King's Mirror. As in the cases of Greek, Latin, and Old French, it is important not only to count the number of separate works, but equally to appreciate their volume and, in many cases, their multiple copies and redactions.

Among the first texts in this new wave were adaptations of classical and contemporary Latin mythological and historical narratives: first and foremost, very well-compiled works of Trojan, Roman and world history, as well as of parts of Geoffrey of Monmouth's history, all of which is very similar to what was happening in French literature at the time. ${ }^{115}$ Another remarkable early text was the apparently first contemporary king's saga, the story of the Norwegian pretender Sverrir (d. 1202), his successful struggle for power, and his conflict with other pretenders and with the bishops (also known through his polemical treatise Against the Bishops). The first, smaller, part was written by an Icelandic abbot under the instruction of Sverrir himself already in the years c. 1185-1188, while the bulk of the text was only composed somewhere between 1214 and $1223 .{ }^{116}$ Among the early narratives one should also count one or more versions of the long saga of Norway's patron saint, Olav Haraldsson. Within a decade or two such texts broke new ground and spawned rewritings, additions, new translations and new narratives. Two characteristics of this prose production are important to note here. In terms of authorship, subject matter and circulation most of these texts travelled back and forth between Iceland and Norway - it was a commonwealth of literature. Secondly, they established a specific concrete, paratactic style of narration, even when translated from Latin, which had many similarities to the anonymous early French prose; they were both attuned to a certain non-Latinate aristocratic audience.

As in the other cases, laws were taken down early, as were some texts related to ecclesiastical learning, but in volume and range they were negligible in comparison with the avalanche of texts around 1200. So, as in French literature, we see a new idea of composing prose for an immediate audience as well as for an accumulating vernacular library and cultural memory. Such a scenario does not solve the problem of the origin of the sagas of early Icelanders, but it can frame it in a new way: the idea of writing and reading sagas could simply not have

115 These were later supplemented with the Alexander story adapted from Gauthier de Chatillon's Alexandreis; for all these texts see Würth, "Antikenroman in der isländischen Literatur.

116 For this text see Bagge, From Gang Leader; for the dates ibid., 15-17. 
occurred to anyone before the book-historical turn in the period c. 1190/1200-1230 - and this turn came about, on the basis of clerical writing, in exactly the same decades as did the French.

\section{Implications}

1. Chronology and contingency

By shifting the research question away from the sorigin or sinvention< of prose to its success, and by insisting that the success of prose must be understood as much by the horizon of writing in terms of dissemination, storing and reading as in terms of authorship, a dynamic pattern for the four literatures in question can be observed: in a matter of three or four critical decades a whole new literary field is established: for Greek c. 420-380, for Latin c. 13090, for French and Old Norse c. 1190/1200-1230. In those same decades, we must assume, the relevant aristocratic networks also became characterized by their relationship to books written in the same language (though different in register, length or complexity) as that of their oral communication.

The significant clustering, or »breakthrough", in all four cases, however, should not lead to any conclusions about the inevitability of this new book culture. It is possible to point to specific cultural and political environments which employed prose writing in the four languages considered - and both medieval cases have been framed by leading scholars in political terms - but one should not refrain from asking the counterfactual question: could the prose turn have happened fifty years earlier or fifty years later than it actually did? A number of social, cultural, educational, and technological factors certainly need to be in place, but in none of the cases do I see any constraints that would have made its rise unthinkable half a century earlier, nor its deferral until fifty years later. While we may eventually be able to line up more factors which favoured exactly these short periods (including specific political scenarios), it is worth keeping in mind that the interplay between elite cultures, knowledge, entertainment, education, book technology, book markets, literary forms, and reading and storage habits are so complex that we have to accept an element of contingency. We can point to a series of necessary conditions and strong arguments can be made for why prose emerged in a larger chronological frame, but the fact of those exact decades of the catalytic effect cannot be fully explained. ${ }^{117}$

From this it furthermore follows that the great artistic, philosophical and scientific potential of having a prose literature covering most genres and domains of knowledge in one's own language, which seems so self-evident from a modern perspective, was anything but obvious in Antiquity and the Middle Ages. Even in the unique Greek case where almost all genres of history, philosophy and science burst on the scene almost in a brief intense moment, there is a strong element of contingency and sleep-walking: If the momentous consequences had been known, this development could well have been triggered earlier in the fifth century. For the other three cases it is perhaps tempting to ask why they took so long when the power of prose was completely well known in the learned, imperial language (Greek for Latin, Latin for French and Old Norse). But even when a dike had been breached, it took centuries to

117 Cf. Moretti Graphs, Maps, Trees, 26: »And problems without a solution are exactly what we need in a field like ours, where we are used to asking only those questions for which we already have an answer.« 
overflow the whole known terrain. The perspective should rather be inverted: the imperial language continued to do its comprehensive work very efficiently, and the transfer of literary forms, scientific structures and specialized vocabulary was always a laborious process. In Latin it took about two centuries to conquer all fields from Greek (from c. 100 BC to the Flavian age, though continuously with new input from and direct use of Greek); in French it was completed only by the sixteenth or seventeenth century (with continuous and even expanding use of Latin); and Old Norse fell into disuse as a written standard by the same time while only having conquered some domains. ${ }^{118}$ In all cases there was a long period with a division of labour between the imperial language and the vernacular in question; from a modern, nationalizing perspective this seems to have been a "slowing down «of the independence and full control of the national language, even when prose books had already become a habit in the vernacular.

In assessing the possibly contingent circumstances of the four cases treated here one should also sustain a sideways glance at written languages which failed to acquire a critical mass of prose book writing even after they had had their Cato. Notker Labeo's elaborate translations from Latin to German from c. 1000 did not create any new space and had been forgotten when a thriving German book culture emerged in the thirteeenth century; medieval Danish remained an exotic experiment until the fifteenth and sixteenth centuries in spite of a strong opening with the The Jutish Law of 1241; Gothic was launched on a high level already in the fourth century with Wulfila's New Testament, but in spite of the interest and support of Gothic rulers during the fifth and sixth centuries never appears to have moved beyond sporadic document writing. With the wisdom of hindsight these can be thought of as false starts, but interestingly, they conform in their material to the successful cases: adaptations of classical texts, laws and Biblical translations formed the basis of the experiments.

While the four suggested short chronologies should be judged each on its own merit, their comparison in any case entails two other observations which are usually neglected in mono-lingual literary history. First, the rise of prose in a vernacular language (including Latin in Rome) cannot be accounted for without considering the division of labour between the learned/imperial language and the vernacular; it is not enough to refer to Greek/Latin as just a "source« or background for certain texts. There is a continuous dynamic between the new and the established which is operative centuries beyond the birth of a new prose literature. Secondly, the coincidence between the chronologies of Old French and Old Norse prose strongly suggests a connection. Influences from French literature on Old Norse have always to a certain extent and in specific cases been acknowledged, but the connection may be more about fundamental social values than just textual convergences. The whole idea of an aristocracy that appreciates stories and learning from vernacular books may simply be the same fashion expressed at the same time in two transregional elites with wide-ranging and overlapping overseas networks.

118 Written Old Norse gave way in the sixteenth century in Iceland to modern Icelandic and in Norway to Danish. As an early modern example of "slow conquest « of language domains one could refer to the role of Finnish: Mikael Agricola shaped the written prose language in his New Testament translation from 1548 (see Häkkinen, Spreading the Written Word), but Finnish prose, in both literature and scholarship only emerged in the mid-nineteenth century. Literary Finnish was in the meantime restricted to poetic forms, and the imperial languages, Swedish, German and Latin (and to a lesser degree Russian) were successfully shouldering the load of scholarly, scientific and fashionable literary prose in learned institutions and among the very restricted reading public with Finnish as a first or second language. 


\section{Authorship and authority}

In broad outline all four literatures in question experienced a prose turn when storing and reading books (alone or aloud) in that language became attractive among the highest echelons of society. But the self-fashioning and social positioning through the new medium played out in two very different ways. In both classical literatures the emergence was tied to a rhetorically minded culture which shared a competitive public urban space (in Athens, Syracuse and Rome) and in which identifiable authorship was intrinsic to the success of prose. The new books (scrolls) were circulated in order to bolster individual social, political (and philosophical and scientific) positions: even when the real political or ideological effect was foreclosed, for instance through exile or other kinds of marginalization, the pursuit of honour and the justification of opinions were nonetheless amplified through writing as an extension of a persona of power (or previous or imagined power).

While anonymous or anonymised prose writings were the exception in the original expansive phases of prose in Greek and Latin, it was the rule in the decisive decades of the development of French and Old Norse. The medieval scenario turned on very different constellations of learning and learned personnel servicing the new aristocratic fashion. With a few exceptions such as Sverris saga and Villehardouin's Chronicle, the new vernacular prose literatures did not promote named authors (and rarely patrons), but instead provided the aristocracy with a rich anonymous historical, learned and fictional material which catered to entertainment, education and the formation of a collective memory across wars, travels, and generations. ${ }^{119}$ Much of this anonymous material derived from translations and adaptations, both in French and Old Norse, and as such sometimes acknowledged ultimate authorship, ancient or medieval, though often only vaguely so. ${ }^{120}$ The very fact of clerical/specialist intervention and the making of elaborate vernacular books for princely or other aristocratic collections seems to have lent the material sufficient authority in itself. As the perhaps most striking example of anonymisation we might quote the most widespread Old French chronicle produced in the first decades of prose, the adaptation of the archbishop William of Tyre's Chronicon (updated to 1184), the so-called Éracles (known in 51 medieval copies). William's original work bears the stamp of a clear authorial personality through his prefaces, opinions, moralization and his own presence in the text - one could almost call it homodiegetic history writing. This continues until the end when William became side-lined in the power-games of the Kingdom - in fact his work can be read as a very clear self-fashioning and self-promoting piece. The Éracles does not write William entirely out of the book, it is acknowledged in a couple of places that one William was behind the Latin original, but his eastern perspective, his learning, his opinions, and his own role in the history are completely obliterated. ${ }^{121}$ What was wanted in Paris in $\mathbf{1 2 2 0}$ was the web and chronology of crusader stories which could serve as an aristocratic and partly royal mirror as well as a collective memory, untainted by any disturbing authorial voice. This mode of anonymous, seemingly self-unwinding, story-

119 Sverris saga was partly co-authored by King Sverrir to support his claim of legitimacy, cf. Bagge, From Gang Leader, 15-19. On the complex authorial presence of Villehardouin in his Chronicle, see Beer, In their Own Words, 38-56.

120 The Prose Lancelot circle borrows the authority of Walter Map, and Li Fets des Romains only occasionally credits its Latin models (cf. Beer, In their Own Words, 69 ff.).

121 Cf. Handyside, Old French William of Tyre. 
telling was a main recipe of narrative prose in both Old French and Old Norse in the formative decades, both in translated and original pieces. Thus the first bursts of prose literatures were, respectively, very strongly authored (Greek and Latin) and very weakly so (Old French, Old Norse).

\section{Survival and canonization of poetic literature}

The emergence of prose book storing and reading habits exercised a profound impact on poetic literature, and one might say with Sander Goldberg, it helped constitute it as literature, or with Marisa Galvez, it turned songs (and songbooks) into a literary object. ${ }^{122}$ The presence and dissemination of prose books drew previous poetic writing into a canon under formation and made sure that at least a few precious bits of it survived - the »librarized « book culture grammaticized poetry and enabled a poetological meta-discourse.

These effects can easily be exemplified in the Greek, Latin and Old Norse cases. ${ }^{123}$ Homer was in one sense saved for posterity when the Iliad and the Odyssey were taken down in writing in the sixth century BCE (or seventh according to a majority of scholars) in one or two copies, but in another by the proliferation of the text by Plato's generation; the same holds true for the small corpus we possess of early Greek lyric poetry. The immense losses of fifth century drama from Athens and Syracuse speak for themselves: a few plays only survived because they became library and reading material in the fourth century; both epic and drama were canonized and theorized by Plato, Aristotle and other intellectuals during or after the breakthrough of prose. In Rome too we recognize these stages. The saving operation of third- and second-century BCE epic and drama was contemporary with the prose turn in the late second century and the rise of a (prose) grammatical and poetological meta-discourse. In Old Norse, skaldic verse owes its written existence to prose chronicles, and the Edda is only known from the prosimetric poetology by Snorri and a possibly contemporary anthology - all texts made possible by the success of prose. Occitan troubadour lyric also largely survived due to partly prosimetric anthologies from the thirteenth century (the Italian chansonnieres) and through its theorization by Ramon Vidal (exactly around 1200), ${ }^{124}$ while the relationship between the long verse romance form and the success of prose, as discussed above, can be understood in at least two ways, both of which gives a significant role to early thirteenth-century vernacular book culture and reading habits.

\section{The power of prose books}

It has been assumed throughout this paper that books, including scrolls and booklets, with prose should be treated as a phenomenon distinct from shorter forms such as glosses, lists, inscriptions, and letters. The argument for this has mainly been one of storing and reading: prose books are written within a broader space of survival and use than a list, a gloss or a

122 Goldberg, Constructing Literature, 18; Galvez, Songbook, 17.

123 This large question falls outside the scope of the present article and I can only just mention the new status of poetry as something that is quoted, anthologized and canonized in writing and its link to the prose turn. For comprehensive treatments of the major poetic forms within an established book culture I refer to Skafte Jensen, Writing Homer, 261-280; Goldberg, Constructing Literature; Nordal, Tools of Literacy; Armstrong and Kay, Knowing Poetry; Galvez, Songbook.

124 Cf. Galvez, Songbook, 57-97. For an excellent large-scale contextualisation of Ramon Vidal's »vernacular manifesto" (Razos de trobar), Beecroft, Ecology of World Literature, 168-170. 
letter. Prose books for circulation also represent a different kind of written speech act than books of very restricted access such as poetic works, biblical translations and laws, all usually authorized by their poetic professionalism, their scriptural exegesis or the legal expertise of law-code keepers. Without a widened horizon of reading, the composition and copying of Thucydides' History, Scaurus' Autobiography, the Éracles and the Legendary Saga of Olav, and all of the other contemporary works listed above, make little sense.

The long-term effects of a successful prose mode are too many to be summarized here, and they can furthermore only be properly analysed for the entire system of relevant languages, because, to stay in this context, Greek remained a crucial resource for Latin, and Latin likewise for a large number of medieval and early modern European languages. But I would like to end by just mentioning at least two consequences of those distant dynamic starts which are still with us today.

One is related to the length and complex structuring of texts that prose enables on a larger scale than poetic forms. While long and complex poetic forms obviously existed both before and alongside prose texts, the sheer amount and flexibility of prose histories, biographies, diaries, romances, novels, treatises, instructions and more, adds continuously and immensely to an ever-growing cultural archive and memory in a discursive and accumulative mode that goes radically beyond what could be achieved by poetic forms. By the modern age prose writing has become such a given that it makes it difficult to understand why it is not natural; it is perceived as an integrated part of all written languages, and the almost infinite archive of prose texts of all sorts is understood as an equally natural part of cultural memory in that language. The accumulation of knowledge stored in writing saw a fresh start with the success of prose.

A qualitative point can also be made. Writing prose became a new way of thinking - one that is familiar to all academics and authors today. The creative side of writing longer texts is facilitated by the space opened up by prose between concepts, arguments and narrative; this potential was already fully exploited in the Greek prose turn while the other literatures in question took on new layers of complexity more gradually. From scientific, philosophical and theological texts on one hand to historical, biographical and fictional narratives on the other, one will always find a balance between a key conceptual framework, an argumentative and a narrative line; no argument is entirely without narrative, and no narrative entirely without an argument; ${ }^{125}$ and neither arguments nor narrative can be sustained without being anchored in key concepts which are displayed and negotiated along the way. As most authors would agree, this way of thinking would not exist without prose writing.

\section{Acknowledgements:}

This work was supported by the National Danish Research Foundation under Grant no. DNRF102ID. For generous help and discussions of the topic and the article the author is indebted to Christian Høgel, Elizabeth Tyler, Henry Bainton, Tom Pettitt, Tim Rowbotham, Patrick Kragelund, Minna Skafte Jensen, Jonas Wellendorf, Kristin Bourassa and Ilona Pikkanen.

125 Lang, Anatomy of Philosophical Style; White, Content of the Form. 


\section{References}

Agapitos, Panagiotis and Lars Boje Mortensen, Introduction, in: Panagiotis Agapitos and Lars Boje Mortensen (eds.), Medieval Narratives between History and Fiction: From the Centre to the Periphery of Europe (c. 1100-1400) (Copenhagen, 2012) 1-24.

Von Albrecht, Michael, Geschichte der römischen Literatur von Andronicus bis Boethius, 2 vols. (2nd edition) (München, 1994).

Andersson, Theodore M., The Growth of the Medieval Icelandic Sagas (1180-1280) (Ithaca, 2006).

Andersson, Theodore M., From Tradition to Literature in the Sagas, in: Else Mundal and Jonas Wellendorf (eds.), Oral Art Forms and their Passage into Writing (Copenhagen, 2008), 7-17.

Andersson, Theodore M., The Partisan Muse in the Early Icelandic Sagas (1200-1250) (Ithaca, 2012).

Anglo-Norman Dictionary [online]. Retrieved on 12 June 2017: www.anglo-norman.net/gate/.

Armstrong, Adrian, and Kay, Sarah, Knowing Poetry: Verse in Medieval France from the "Rose" to the "Rhétoriqueurs" (Cornell, 2011).

Asper, Markus, Medienwechsel und kultureller Kontext. Die Entstehung der griechischen Sachprosa, in: Jochen Althoff (ed.), Philosophie und Dichtung im antiken Griechenland, (Stuttgart, 2007) 67-102.

Astin, Alan E., Cato the Censor (Oxford, 1978).

Aurell, Martin, Le chévalier lettré - Savoir et conduite de l'aristocratie aux XIIe et XIIIe siècles (Paris, 2011).

Bagge, Sverre, From Gang Leader to the Lord's Anointed: Kingship in Sverris Saga and Hákonar Saga Hákonarsonar (Odense, 1996).

Baumgartner, Emmanuele, Le choix de la prose, Cahiers de recherches médiévales et humanistes 5 (Le choix de la prose) (1998) 7-13.

Beecroft, Alexander, An Ecology of World Literature: From Antiquity to the Present Day (London, 2015).

Beer, Jeanette, In their Own Words: Practices of Quotation in Early Medieval History-Writing (Toronto, 2014).

Benton, John F., Culture, Power and Personality in Medieval France (London, 1991).

Bernard of Clairvaux, Sermons on the Song of Songs, ed. Stewart Gregory: La traduction en prose française du 12e siècle des Sermones in Cantica de Saint Bernard (Amsterdam, 1994).

Buoncompagno da Signa, Palma, ed. Carl Sutter, Aus Leben und Schriften des Magisters Boncompagno. Ein Beitrag zur italienischen Kulturgeschichte des dreizehnten Jahrhunderts (Freiburg, 1894).

Burns, Jane E., 1209? Arthurian Romance in Prose, in: Denis Hollier (ed.), A New History of French Literature (Cambridge Mass., 1989) 66-70.

Candau, José M., Republican Rome: Autobiography and Political Struggles, in Gabriele Marasco (ed.), Political Autobiographies and Memoirs in Antiquity. A Brill Companion (Leiden, 2011) 121-59.

Ceccarelli, Paola, Ancient Greek Letter Writing: a Cultural History (6oo BC-15O BC) (Oxford, 2013).

Cicero, De legibus, transl. Clinton Walker Keyes (Cambridge, 1928).

Cicero, De legibus, ed. Konrat Ziegler (Würzburg, 1979).

Clover, Carol J., The Long Prose Form, Arkiv för Nordisk Filologi 101 (1986) 10-39. 
Cornell, Timothy J. (ed.), The Fragments of the Roman Historians, Vol. I: Introduction (Oxford, 2013).

Dembowski, Peter F., Learned Latin Treatises in French: Inspiration, Plagiarism, and Translation, Viator 17 (1986) 255-269.

Dictionnaire du Moyen Français (1330-1500) [internet]. Retrieved on 12 June 2017: http:// www.atilf.fr/dmf/.

Dictionary of Medieval Latin from British Sources, ed. Ronald Edward Latham, David R. Howlett and Richard K. Ashdowne (Oxford, 1975-2013).

Dugan, John, Making a New Man: Ciceronian Self-Fashioning in the Rhetorical Works (Oxford, 2005).

Duggan, Joseph J. The Romances of Chrétien de Troyes (New Haven, 2001).

Farrell, Joseph, Latin Language and Latin Culture from Ancient to Modern Times (Cambridge, 2001).

Fedorenko, Gregory, The Texts, Manuscripts and Historical Significance of the Prose Chronique de Normandie and Geste de France (c.1180-c.1230). Unpublished PhD thesis (University of Cambridge, 2012).

Feeney, Dennis, The Beginnings of Roman Literature, Journal of Roman Studies 95 (2005) 226-240.

First Grammatical Treatise: the Earliest Germanic Phonology, ed. and trans. Einar Haugen (London 1950, 2nd edition 1972).

Frye, Northrop, The Great Code: the Bible and Literature (New York, 1982).

Gagarin, Michael, Early Greek Law (Berkeley, 1989).

Galvez, Marisa, Songbook: How Lyrics Became Poetry in Medieval Europe (Chicago, 2012).

Gaunt, Simon, Retelling the Tale: an Introduction to Medieval French Literature (London, 2001).

Gaunt, Simon, French Literature Abroad: Towards an Alternative History of French Literature, Interfaces - A Journal of Medieval European Literatures 1 (2015) 25-61.

Gillespie, Alexandra, The History of the Book, New Medieval Literatures 9 (2007) 245-286.

Godzich, Wlad and Kittay, Jeffrey, The Emergence of Prose: an Essay in Prosaics, (Minneapolis, 1987).

Goldberg, Sander M., Constructing Literature in the Roman Republic: Poetry and its Reception (Cambridge, 2005).

Goldberg, Sander M., The Early Republic: the Beginnings to 90 BC, in: Stephen Harrison (ed.), A Companion to Latin Literature (Oxford, 2005), 15-30.

Goldhill, Simon, The Invention of Prose (Oxford, 2002).

Green, Dennis H., Medieval Listening and Reading: the Primary Reception of German Literature 800-1300 (Cambridge, 1994).

Green, Dennis H., Women Readers in the Middle Ages (Cambridge, 2007).

Grévin, Benoit, Rhétorique du pouvoir médiéval. Les Lettres de Pierre de la Vigne et la formation du langage politique européen (XIIIe-XVe siècle) (Rome, 2008).

Grévin, Benoit, Les frontières du >dictamen<. Structuration et dynamiques d'un espace textuel médiéval (XIIIe-XVe s.), Interfaces - A Journal of Medieval European Literatures 1 (2015) 142-169.

Gulley, Norman, Review of Havelock, Preface to Plato, The Classical Review, 14/1 (1964) 31-33.

Habinek, Thomas, The World of Roman Song: From Ritualized Speech to Social Order (Baltimore, 2005).

Hägg, Tomas, The Art of Ancient Biography (Cambridge, 2012). 
Häkkinen, Kaisa, Spreading the Written Word: Mikael Agricola and the Birth of Written Finnish (Helsinki, 2015).

Handyside, Philip, The Old French William of Tyre (Leiden, 2015).

Havelock, Eric, Preface to Plato (Oxford, 1963).

Havelock, Eric, The Muse Learns to Write: Reflections on Orality and Literacy from Antiquity to the Present (New Haven, 1986).

Havelock, Eric, The Linguistic Task of the Presocratics, in: Kevin Robb (ed.), Language and Thought in Early Greek Philosophy (La Salle, 1983) 7-82.

Helle, Knut, Gulatinget og Gulatingslova (Leikanger, 2001).

Hoff, Hans Henning, Haflidi Másson und die Einflüsse des römischen Rechts in der Grágás (Berlin, 2012).

Høgel, Christian, World Literature is Trans-imperial: a Medieval and a Modern Approach (forthcoming).

Jensson, Gottskálk, Were the Earliest fornaldarsögur Written in Latin?, in Agneta Ney, Ármann Jakobsson and Annette Lassen (eds.): Fornaldarsagaerne: Myter og virkelighed; Studier $i$ de oldislandske "fornaldarsögur Norðurlanda" (Copenhagen, 2009) 79-91.

Kragelund, Patrick, Roman Historical Drama: the Octavia in Antiquity and Beyond (Oxford, 2016).

Kurke, Leslie, Aesopic Conversations: Popular Tradition, Cultural Dialogue, and the Invention of Greek Prose (Princeton, 2010).

Lambert of Ardres, The History of the Counts of Guines and Lords of Ardres, ed. and trans. Leah Shopkow (Philadelphia, 2001).

Lang, Berel, The Anatomy of Philosophical Style: Literary Philosophy and the Philosophy of Literature (Oxford, 1990).

Lassen, Annette, Origines Gentium and the Learned Origin of Fornaldarsögur Norðurlanda, in Annette Lassen, Agneta Ney and Ármann Jakobsson (eds.): The Legendary Sagas: Origins and Development (Reykjavík, 2012) 33-58.

Li fet des Romains, ed. Louis-Fernand Flutre and Kornelis Sneyders de Vogel (Paris, 19371938).

McTurk, Rory (ed.), A Companion to Old Norse-Icelandic Literature and Culture (Oxford, 2005).

Meulengracht Sørensen, Preben, Kapitler af Nordens litteratur i oldtid og middelalder (Aarhus, 2006).

Mittellateinisches Wörterbuch bis zum ausgehenden 13. Jahrhundert, vol. II, ed. Otto Prinz and Johannes Schneider (München, 1999).

Moretti, Franco, Graphs, Maps, Trees (London, 2005).

Mortensen, Lars Boje, Den formative dialog mellem latinsk og folkesproglig litteratur ca 60o-1250. Udkast til en dynamisk model, in: Else Mundal (ed.): Reykholt som makt- og lærdomssenter $i$ den islandske og nordiske kontekst (Reykholt, 2006) 229-271.

Mortensen, Lars Boje, Nordic Medieval Texts: Beyond `Literature and `Sourcesı. Reflections on Expanding Interdisciplinary Border Zones, Saga-Book. Viking Society for Northern Research (2014) 95-112.

Mortensen, Lars Boje, Comparing and Connecting: the Rise of Fast Historiography in Latin and Vernacular (12th-13th cent.) Medieval Worlds 1 (2015) 25-39.

Mortensen, Lars Boje, Latin as Vernacular: Critical Mass and the sLibrarization Languages, in: Norbert Kössinger et al. (eds.), Origin Stories: The Rise of Vernacular Literacy in a Comparative Perspective (Munich, 2017) forthcoming. 
Müller, Stephan, Gute Geschichte/n: Literarische Selbsterfindungen und die Geschichte der Literatur des Mittelalters, Interfaces - A Journal of Medieval European Literatures 1 (2015) 92-109.

Mundal, Else, Introduction, in Else Mundal (ed.): Dating the Sagas. Reviews and Revisions, (Copenhagen, 2013) 1-8.

Mundal, Else, Sagalitteraturen, in: Odd Einar Haugen (ed.): Handbok i Norrøn Filologi (Bergen, 2004) 267-302.

Munk Olsen, Birger, L'Étude des auteurs classiques latins aux XIe et XIIe siècles, vol III.1 Les Classiques dans les bibliothèques médiévales (Paris, 1987).

Musti, Domenico, Il pensiero storico romano, in Guglielmo Cavallo, Paolo Fedeli and Andrea Giardina (eds.), Lo spazio lettarario di Roma antica, vol. I, La produzione del testo (Roma, 1990) $177-240$.

Nagy, Gregory, Hesiod and the Ancient Biographical Traditions, in: Franco Montanari, Antonios Rengakos, and Christos Tsagalis (eds.), The Brill Companion to Hesiod (Leiden, 2009) 271-311.

Narducci, Emanuele, Cicerone e l'eloquenza romana: Retorica e progetto culturale (Roma, 1997).

Nordal, Gudrun, Tools of Literacy: the Role of Skaldic Verse in Icelandic Textual Culture of the Twelfth and Thirteenth Centuries (Toronto, 2001).

Norden, Eduard, Die Antike Kunstprosa (Leipzig, 1898).

O'Donnell, Thomas, Anglo-Norman Multilingualism and Continental Standards in Guernes de Pont-Sainte-Maxence's Vie de Saint Thomas, in: Elizabeth M. Tyler (ed.), Conceptualizing Multilingualism in England, 800-1250 (Turnhout, 2011) 337-356.

O'Donnell, Thomas, 'The Ladies Have Made Me Quite Fat $₫$ : Authors and Patrons at Barking Abbey, in: Donna A. Bussell and Jennifer N. Brown (eds): Barking Abbey and Medieval Literary Culture (Woodbridge, 2012) 94-114.

Ong, Walter J., Orality and Literacy (London, 1982).

Pausanias, Description of Greece, trans. W.H.S. Jones, Henry Arderne Ormerod and R. E. Wycherley, 4 vols. (Cambridge, MA, 1918).

Plato, Phaedrus, trans. Christopher J. Rowe (Warminster, 1986).

Pollock, Sheldon, The Language of Gods in the World of Men: Sanskrit, Culture, and Power in Premodern India (Berkeley, 2006).

Philippe de Navare, Les Quatre ages de l'homme, ed. Marcel de Fréville (Paris, 1888).

Rector, Geoff, En sa chambre sovent le lit: Literary Leisure and The Chamber Sociabilities of Early Anglo-French Literature (c. 1100-1150), Medium Avvum 81/1 (2012) 88-125.

Robert de Clari, La conqûete de Constantinople, ed. Jean Dufournet (Paris, 2004).

Schanz, Martin and Hosius, Carl, Geschichte der römischen Literatur I (München, 1927).

Sciarrino, Enrica, Cato the Censor and the Beginnings of Latin Prose: From Poetic Translation to Elite Transcription (Columbus, 2011).

Solmsen, Friedrich Review of Havelock, Preface to Plato, The American Journal of Philology 87/1 (1966) 99-105.

Spiegel, Gabrielle M., Romancing the Past: the Rise of Vernacular Prose Historiography in Thirteenth-Century France (Berkeley, 1993).

Skafte Jensen, Minna, Writing Homer: a Study Based on Results for Modern Fieldwork (Copenhagen, 2011).

Stempel, Wolf-Dieter, Die Anfänge der romanischen Prosa im XIII. Jahrhundert, in: Hans R. Jauss and Erich Köhler (eds.), Grundriss der Romanischen Literaturen des Mittelalters, Vol. I (Generalités) (Heidelberg, 1972), 585-601. 
Stempel, Wolf-Dieter, Entwicklungsperspektiven des historiographischen Diskurses in altfranzösischer Zeit, in Hans Ulrich Gumbrecht, Ursula Link-Heer, and Peter-Michael Spangenberg (eds.), La litterature historiographique des origines a 1500 (Grundriss der Romanischen Literaturen des Mittelalters XI/I/3) (Heidelberg, 1987) 708-733.

Stirnemann, Patricia Danz, Quelques bibliothèques princières e la production hors scriptorium au XIIe siècle, Bulletin archéologique du Comité des travaux historiques et scientifiques, n.s. 17-18A (1984) 7-38.

Suerbaum, Werner (ed.), Die Archaische Literatur. Von den Anfängen bis Sullas Tod. Die vorliterarische Periode und die Zeit von 240 bis 78 v. Chr., Handbuch der Lateinischen Literatur der Antike 1 (München, 2002).

Too, Yun Lee, The Idea of the Library in the Ancient World (Oxford, 2010).

Tulinius, Torfi, The Matter of the North: the Rise of Literary Fiction in Thirteeth-Century Iceland (Odense, 2002).

Van der Toorn, Karel, Scribal Culture and the Making of the Hebrew Bible (Cambridge, Mass., 2007).

Velleius Paterculus, Historia Romana, trans. Frederick W. Shipley (Harvard, 1924).

Wellendorf, Jonas, Lærdomslitteratur, in Odd Einar Haugen (ed.), Handbok i Norrøn Filologi (second edition) (Bergen, 2013), 302-335.

White, Hayden, The Content of the Form: Narrative Discourse and Historical Representation (John Hopkins, 1990).

Wiseman, Peter, Unwritten Rome (Exeter, 2008).

Wiseman, Peter, The Roman Audience: Classical Literature as Social History (Oxford, 2015).

Witt, Ronald G., The Two Latin Cultures and the Foundation of Renaissance Humanism in Medieval Italy (Cambridge, 2012).

Wöhrle, Georg, Zur Prosa der milesischen Philosophen, Würzburger Jahrbücher für die Altertumswissenschaft 18 (1992) 33-47.

Woledge, Brian, La légende de Troie et les débuts de la prose française, Mélanges de linguistique et de littérature romanes offerts à Mario Roques vol. 2, (Bade, 1953).

Woledge, Brian and H. P. Clive, Répertoire des plus anciens texts en prose française depuis 842 jusqu'aux premières années du XIIIe siècle (Genève, 1964).

Würth, Stefanie, Der »Antikenroman « in der isländischen Literatur des Mittelalters. Eine Untersuchung zur Übersetzung und Rezeption lateinischer Literatur im Norden (Basel, 1998).

Zimmermann, Bernhard, Die Literatur der archaischen und klassischen Zeit (Handbuch der Griechischen Literatur der Antike, vol. 1) (München, 2011).

Zink, Michel, Medieval French Literature: an Introduction (transl. by Jeff Rider) (Binghamton, 1995). 